NBER WORKING PAPER SERIES

\title{
HARVESTS AND FINANCIAL CRISES IN GOLD-STANDARD AMERICA
}

\author{
Christopher Hanes \\ Paul W. Rhode \\ Working Paper 18616 \\ http://www.nber.org/papers/w18616
}

\author{
NATIONAL BUREAU OF ECONOMIC RESEARCH \\ 1050 Massachusetts Avenue \\ Cambridge, MA 02138
}

December 2012

Thanks to Michael Bordo, Charles Calomiris, Joseph Ferrie, John James, Jon Moen, Hugh Rockoff, Alan Taylor, Ellis Tallman, Marc Weidenmier, David Weiman, Eugene White and Gavin Wright. The views expressed herein are those of the authors and do not necessarily reflect the views of the National Bureau of Economic Research.

NBER working papers are circulated for discussion and comment purposes. They have not been peerreviewed or been subject to the review by the NBER Board of Directors that accompanies official NBER publications.

(C) 2012 by Christopher Hanes and Paul W. Rhode. All rights reserved. Short sections of text, not to exceed two paragraphs, may be quoted without explicit permission provided that full credit, including (C) notice, is given to the source. 
Harvests and Financial Crises in Gold-Standard America

Christopher Hanes and Paul W. Rhode

NBER Working Paper No. 18616

December 2012

JEL No. E32,E4,N11

\begin{abstract}
$\underline{\text { ABSTRACT }}$
Most American financial crises of the postbellum gold-standard era were caused by fluctuations in the cotton harvest due to exogenous factors such as weather. The transmission channel ran through export revenues and financial markets under the pre-1914 monetary regime. A poor cotton harvest depressed export revenues and reduced international demand for American assets, which depressed American stock prices, drained deposits from money-center banks and precipitated a business-cycle downturn - conditions that bred financial crises. The crises caused by cotton harvests could have been prevented by an American central bank, even under gold-standard constraints.
\end{abstract}

Christopher Hanes

Dept. of Economics

SUNY Binghamton

P.O. Box 6000

Binghamton, NY 13902-6000

chanes@binghamton.edu

Paul W. Rhode

Economics Department

University of Michigan

205 Lorch Hall

611 Tappan St.

Ann Arbor, MI 48109-1220

and NBER

pwrhode@umich.edu 
In the pre-1914 gold-standard era, the American economy suffered financial crises more frequently than other countries (Bordo, 1985) with all the usual symptoms: mass withdrawals of funding from financial intermediaries, choked-off credit supply and payment-system breakdowns. Economists believe America was especially vulnerable to financial crises because it had no central bank to act as lender of last resort, and its banks were not allowed to form branch networks to diversify risk. But these structural features of the financial system do not explain why a crisis occurred in one year rather than another. It is important to identify the exogenous factors that triggered pre-1914 crises, not just to complete the historical account but to advance economic research. Recent studies have used data from the pre-1914 U.S. (among other times and places) to identify antecedents and peculiar effects of financial crises in general (e.g. Reinhart and Rogoff, 2011; Bordo and Haubrich, 2010; Schularick and Taylor, 2012). For such purposes one must be able to distinguish effects of a crisis per se from the conditions that triggered it and from those conditions' other repercussions.

Before 1914, contemporary observers believed that monetary shocks originating in agriculture caused many of America's financial crises. Rural households and businesses made relatively little use of bank accounts, so payments associated with autumn harvests and spring planting created seasonal surges of demand for cash. To accommodate them, rural banks withdrew their deposits in financialcenter banks, leaving the latter with low reserves of liquid assets. Thus, a further decrease in deposits or increase in loan defaults that would be shrugged off in other seasons could touch off a crisis in autumn or spring (Sprague, 1910, p. 127; Kemmerer, 1911, p. 48). Apart from seasonal effects on money demand, contemporaries believed year-to-year fluctuations in harvests of America's major export crops, cotton and wheat, could affect money supply and hence financial conditions through the gold-standard specie-flow mechanism. America was part of the international gold standard system from January 1879, when the Treasury began to redeem currency in gold, until the First World War when most countries suspended gold convertibility. According to A. Piatt Andrew (1906, p. 326): the size of the crops will exert a considerable influence upon the balance of trade and the 
international movement of gold. The extent of bank reserves in the great financial centres and the contraction or expansion of general credit may in consequence depend most importantly upon the output of the season's harvests... When the American crops are abundant, our exports very naturally tend to increase, and gold imports are apt to occur... When, on the other hand, the movement of exports and of gold swings in the contrary direction, ..we are apt to be confronted with dwindling bank reserves, a contingent contraction of the general credit, declining business, and less activity in trade.

Because agricultural shocks to cash demand and export revenue were transitory, a central bank could have sterilized them by adjusting the supply of an "elastic" currency - nongold high-powered money without endangering the country's commitment to the gold standard. Thus, in the policy debates leading up to the foundation of the Federal Reserve, proponents of a central bank for the United States frequently invoked agricultural shocks' purported disruptions to financial conditions (Wicker, 2005).

In modern economic literature, Miron (1986) supports this old view, arguing that seasonal peaks in rural activity raised interest rates, drained bank reserves and raised the probability of panics; that realized panics probably caused business-cycle downturns; and that the creation of the Fed eased these problems. But a more common view in modern literature appears to have little role for monetary shocks originating in agriculture. Gorton (1988), Wilson, Sylla and Jones (1990), Mishkin (1991), and Calomiris and Gorton (1991) argue that pre-1914 crises were effects rather than causes of businesscycle downturns: depositors withdrew en masse because they feared a recession would endanger banks' solvency. Thus Calomiris and Gorton discount the argument that money-supply adjustments by a central bank could have prevented crises (p. 165).

In this paper, we re-examine the relation between agriculture and American financial crises of the pre-1914 gold standard era. We provide evidence that most of the era's crises were caused by fluctuations in harvests of one crop, cotton, due to exogenous factors such as weather and pests. Using regional weather data as instruments, we show that a poor cotton harvest created the preconditions for a pre-1914 financial crisis: it drained deposits from financial-center banks, depressed stock prices and precipitated a cyclical downturn in the industrial economy. Wheat harvest fluctuations did not have these effects. We argue that harvests' financial effects reflected their impact on rural cash demand and 
the potential supply of high-powered money under the gold standard, as argued by contemporaries. But transmission ran through international capital markets rather than the classic specie-flow mechanism.

International demand for American assets was sensitive to the spread between expected returns on American versus European assets. The sum of capital inflow and net exports was constrained by the rate of growth in high-powered money demand, as growth in the money supply was about equal to the balance of payments. Putting these two conditions together, a negative shock to American net exports could be balanced either by a simultaneous negative shock to high-powered money demand, or by an increase in required returns on American assets. The effect of a crop's harvest on financial conditions depended on the strength of its effect on export revenue relative to its effect on rural cash demand. For cotton, the export-revenue effect was relatively strong, so a poor cotton harvest depressed prices of American securities, drained deposits from New York banks by raising short-term interest rates, and depressed real economic activity with the usual lag of six months to year in the effect of monetary shocks. Wheat was an export crop, but its cash-demand effect was strong relative to its export-revenue effect. Thus, wheat harvests affected international gold flow, but not American financial conditions.

To begin, we define and describe American financial crises in the pre-1914 gold standard era and review existing literature on their causes. Next we hypothesize possible effects of shocks to export revenue versus money demand on American financial markets under the pre-1914 monetary regime. Then we observe actual effects of harvest fluctuations with regressions on time-series data. Finally we look at realized cotton harvests and key variables in crisis years. Appendix 1 gives data sources.

\section{1) Our definition of financial crises}

Our definition of crises is conventional. Following Sprague (1910), Wilson, Sylla and Jones (1990), Calomiris and Gorton (1991), Wicker (2000) and others, we define a national financial crisis as a general run on banks in New York City, and identify such events objectively by the actions of the New York Clearing House (NYCH). When NYCH directors perceived that a general run was underway or imminent, they authorized the issuance of clearinghouse loan certificates (Wicker, 2000, 
p. 116). Certificates substituted for cash in interbank payments, freeing up banks' cash to pay off withdrawals. They were issued when a bank applied to the $\mathrm{NYCH}$ for a loan and $\mathrm{NYCH}$ agents deemed the bank a good risk after examining its books (which may have helped verify the bank's solvency to the public).

We are particularly interested in the era when America was part of the international gold standard, from 1879 to 1913 . We do not include 1914 in our analysis because the outbreak of WWI created financial disturbances of obviously foreign origin. Table 1 lists the crises that occurred within 1879-1913 according to various studies. All studies identify crises in 1884, 1890, 1893 and 1907, when NYCH loan certificates were issued. Calomiris and Gorton (1991) identify an additional crisis in 1896, when the NYCH authorized certificates (because withdrawals had left many New York banks' cash reserves below legal requirements) but no bank applied for a clearinghouse loan. ${ }^{1}$

Figure 1 plots the log of deposits in NYCH member banks at a monthly frequency with a seasonal adjustment. ${ }^{2}$ There are obvious drops in deposits around the crisis dates of 1884,1893 and 1896. In 1890, according to Wicker (2000), "The speedy authorization to issue loan certificates forestalled the spread of the disturbance" (p. 41); "An incipient panic had been nipped in the bud" (p. 47). In 1907 the first runs occurred at trust companies, which were not NYCH members. At the same point in time that the NYCH authorized loan certificates, it restricted cash payments which effectively froze deposits in NYCH banks. (The NYCH also restricted payments in 1893, but many weeks after it authorized certificates).

A run on banks in New York City - rather than, say, Philadelphia or Chicago - meant a national crisis because of New York's central role in the financial system. New York banks were a key source of funding for the shadow banking system of the era - private banks, brokerage houses and commercial-paper houses. They arranged most loans to firms and individuals who borrowed short-term

\footnotetext{
${ }^{1}$ New York Times Aug. 23 1896, p. 9; Aug. 25, 1896, p. 4; Aug. 26, 1896, p. 1, 10; Sept. 1, 1896, p. 1.
} 
to finance purchases of long-term securities, through overnight "call money" loans or 2-6 month "time money" loans (Myers, 1931, pp. 265-287, 335). On the liability side, New York banks drew interbank deposits - "bankers' balances" - from all parts of the country. Deposits in a New York "correspondent" bank (or in a regional money-center bank that held deposits in New York) were an important liquid asset to nearly all out-of-town banks (James, 1978). An increase in banks' demand for cash reserves or the nonbank public's demand for cash, anywhere in the country, was ultimately covered by withdrawals of bankers' balances and shipments of cash out of New York (unless it was offset by a decrease in demand somewhere else). Thus, widespread bank runs in the hinterland were quickly transmitted to New York, while a run or restriction of payments in New York triggered payments restrictions by other cities' banks and clearinghouses. As a run on New York hindered many types of financial intermediation, it raised the cost of credit and tightened credit rationing (Mishkin, 1991).A New York run also raised transactions costs, because New York bankers' balances were the chief medium of intercity payments: during a crisis payers had to resort to long-distance cash shipments (James, McAndrews, and Weiman, 2011).

All but one of the crisis dates in Table 1 coincided with extraordinarily high rates of bank failures. Bernanke (1983) uses a deposit-weighted failure rate (the fraction of deposits in banks that had been taken over by authorities) to measure the degree of financial disintermediation in the 1930s. For the pre-1914 era, the statistic closest to Bernanke's measure is an asset-weighted failure rate, available at an annual frequency for twelve-month spans ending with June. ${ }^{3}$ Figure 2 shows that this series spikes in the spans containing the crises of 1884, 1893, 1896 and 1907. On this measure, 1896 was indeed a crisis. We classify it as such for the regressions we report below, but our results do not depend on it. 1890 was an exception: though generally considered a crisis, it was not coincident with a

\footnotetext{
${ }^{2}$ We regress the log on monthly dummies, excluding years containing crises. We plot the log less estimated monthly dummies.

${ }^{3}$ U.S. Comptroller $(1921,1931$ pp. 5, 8) gives deposits and assets of failed national banks, monthly. For other failed banks (state, trust companies etc.) it gives assets only, annually July 1 to June 30.
} 
spike in bank failures.

\section{2) Existing literature on causes of crises}

Theoretical models and empirical studies have examined causes of runs on financial intermediaries in many times and places. Generally, they show that runs can occur when lenders to intermediaries, e.g. bank depositors, observe a decline in market values of intermediaries' liquid assets, or come to believe intermediaries' illiquid assets will not pay off: this means some intermediaries may be insolvent. Lenders may withdraw funds from most intermediaries even if they believe only some are insolvent, if they are unsure exactly which intermediaries are at risk (Gorton, 2010), or if they expect the news to cause other lenders to withdraw (Morris and Shin, 2000) in the type of liquidity crisis described by Diamond and Dybvig (1983). A shock is more likely to set off a crisis if it occurs at a time when funds were already being withdrawn from intermediaries (Chari, 1989). In the case of the pre-1914 U.S., the potential cause of a financial crisis would be a set of events, exogenous to the American macroeconomy, that created conditions endangering the solvency of New York banks, especially if they occurred at a time when deposits were already being withdrawn from New York banks.

\section{1) 1890 and 1907: contagion from Europe}

In the post-World War II era, "sudden stops" of foreign investment triggered many financial crises in capital-importing countries of Latin America and Asia (Calvo and Reinhart, 1996; Kaminsky, Reinhart and Vegh, 2003). According to many pre-1914 contemporaries and modern economists (e.g. Sprague 1910, p. 132; Fels 1959, p. 167; Friedman and Schwartz, 1963, p. 104, 156; Eichengreen, 1992, p. 51; Bordo 2006; Reinhart and Rogoff, 2009, p. 243), the American crises of 1890 and 1907 were caused by sudden stops of foreign investment from Europe. This is plausible because an exogenous decline in foreign demand for American assets would tend to depress American stock prices and real activity. A drop in stock prices threatened New York banks as it could bring defaults on their loans to stock market "speculators." A recession could bring defaults on business loans and threatened 
banks all over the country, draining their interbank deposits from New York.

Through most of the pre-1914 era the U.S. imported capital from Europe. Europeans held large fractions of outstanding American securities (Wilkins, 1989). At short maturities, Americans borrowed in London by selling "finance bills," 1-3 month paper "drawn" on a London bank like a trade bill but collateralized by American stocks and bonds like New York time money (Margraff, 1912, pp. 34-42). Through international arbitrage, a hike in European interest rates or a European sell-off of securities in general would tend to raise American interest rates and lower prices of American securities.

1890 was the year of the most notorious European financial disturbance of the pre-1914 era, the "Barings' crisis." Events in South America had caused European investors to fear defaults on Argentine bonds, depressing those bonds' prices and endangering the solvency of London financial houses exposed to them, including Barings'. In July 1890, Barings' and others began fire sales of good assets, including American securities, to raise liquid funds. ${ }^{4}$ Meanwhile, a monetary tightening by the Bank of England hiked rates on London bills, including American-issued finance bills (Sprague, 1910, p. 133).

1907 saw sharp hikes in European bill rates, due to tightening by the Bank of England and other European central banks in response to a persistent international gold drain. According to Odell and Weidenmier (2004), the gold drain reflected payments by European insurance companies for damage from the San Francisco earthquake of 1906. The Bank took further actions to choke off American finance-bill borrowing, specifically (Sprague, 1910, p. 241; Noyes, 1898, p. 358; Sayers, 1976, pp. 54-56).

An increase in American interest rates due to foreign events, hence exogenous to American conditions, would tend to depress American real activity and could precipitate a business-cycle downturn. Calomiris and Gorton (1991) argue that cyclical downturns were the proximate cause of all of the crises listed in Table 1: when people perceived a downturn was underway, they feared a wave of defaults on banks' business loans; panics in the hinterland due to fears for local banks were transmitted

\footnotetext{
${ }^{4}$ Noyes (1898, p. 157), Lauck (1907, p. 64), the Economist (Supplement, Feb. 21, 1891), Wilkins (1989, pp. 194, 222, 471).
} 
to New York as out-of-town banks withdrew bankers' balances to build up their own cash reserves. To support their argument, Calomiris and Gorton point out that all crises occurred in the midst of cyclical downturns according to the NBER business-cycle chronology, and all crises were preceded by big drops in stock prices. They argue these stock-price declines indicated the public expected a recession, which would hit corporate earnings.

Aside from its role as an indicator of expected recession, a drop in stock prices could be a more direct result of foreign financial disturbance. Stock prices reflect required returns to long-term securities as well as expected corporate earnings. An increase in required returns due to international factors would depress American stock prices for any given expectations of future earnings. A drop in stock prices was also a direct threat to the solvency of New York banks, especially. Some New York banks lent to brokerages and other stock "speculators" who could not repay if stock prices fell sharply. The problem was not ordinary call- or time-money loans. These were collateralized with large "haircuts" - margins between collateral value and loan amount - to protect the lender against drops in collateral value. ${ }^{5}$ We have found no evidence of runs due to fears of losses on such loans. The problem was rather that banks made large unsecured loans to speculators, sometimes illicitly, and depositors did not know exactly which banks had done so. Some of the most conspicuous New York runs in 1884, 1890 and 1907 occurred for this reason. This feature of pre-1914 crises appears in contemporary accounts but has escaped the notice of recent literature, so we provide details in Appendix 2.

All the crises in Table 1 were, indeed, preceded by large declines in stock prices. All but one took place during cyclical downturns - the exception is, again, 1890. These patterns are apparent in Figure 3, which plots a monthly index of American stock prices and a seasonally-adjusted version of Miron and Romer's (1990) monthly industrial production (IP) index. The Miron-Romer index begins with January 1884. For earlier years we link it to Davis' (2004) annual IP index, which covers the

\footnotetext{
${ }^{5}$ Haircuts were as large as 30 percent and were larger for portfolios containing riskier assets (Myers, 1931 p. 281). The largest one-day drop in the Dow Jones Industrial Average (in 1914) was less than 25 percent.
} 
entire nineteenth century. ${ }^{6}$ Right-hand columns of Table 1 give dates of business-cycle turning points around crises according to the old NBER chronology and two other chronologies based on more recent research. Romer's (1994) is based on the monthly IP index so it does not cover 1884. She shows that the NBER chronology, which was developed prior to the adoption of the modern definition of business cycles, places some peaks too early and includes some nonexistent downturns (when nominal variables fell but real variables continued to grow). Davis' (2006) peaks and troughs are simply those apparent in his annual IP index. All the chronologies place a downturn prior to the crises of 1884, 1983, 1896 and 1907. Only the NBER's dates a downturn near 1890.

\section{2) What about 1884, 1893 and $1896 ?$}

Like 1890 and 1907, the crises of 1884, 1893 and 1896 were preceded by cyclical downturns and stock-price declines. But none can be plausibly attributed to a foreign financial crises or centralbank tightening. ${ }^{7}$ A political factor that contributed to these crises, but did not trigger them, was the perceived danger that the U.S. would link the dollar to silver and float against gold. "Silver risk" contributed to crises by reducing international demand for American securities. ${ }^{8}$ Silver risk appears to have become negligible after the 1896 presidential election, which was taken to signal firm commitment to the gold standard (Friedman and Schwartz, 1982, pp. 513-517). The literature does not claim that exogenous hikes in silver risk set off crises but rather that potential silver risk was crystallized by, and amplified, cyclical downturns and financial crises already underway. ${ }^{9}$ The more-

\footnotetext{
${ }^{6}$ We regress the log on monthly dummies, excluding years containing crises. We plot the log less estimated monthly dummies. The Miron-Romer series lacks an observation for March 1902. We set the log of that month's value at the average of adjacent months. To link annual and monthly series we set the change from 1883 to 1884 equal to the change from the 1883 annual value to the average of the 1884 monthly values.

7 The Bank of England did not tighten in the couple of years prior to the 1884 crisis (Hawtrey, 1938, pp. 102-103). The closest European financial disturbance before 1884 occurred in January 1882 (Reinhart and Rogoff, 2009, Table A.4.1; Bordo and Eichengreen 1999; Kindleberger, 1996). A contemporary claimed 1893 was "an afterclap of the Barings failure" (Conant, 1909, p. 668) and some modern economists have agreed (e.g. Kindleberger, 1996, p. 121) but this is a wild stretch. As Figures 1 and 3 show, there was a strong recovery between 1890 and 1893 .

${ }^{8}$ It did not spur Americans to withdraw bank deposits for conversion into gold (Sprague, 1910, pp. 165, 169; Friedman and Schwartz, 1963, pp. 108-09).

${ }^{9}$ On 1884, Sprague (1910, pp. 109-110), Fels (1959, pp. 130-131) and Friedman and Schwartz (1963, pp. 100-101) all argue that an increase in perceived silver risk caused foreign sales of U.S. assets, but that the increase in perceived risk was triggered by a prior cyclical downturn. On 1893 Sprague $(1910$, pp. 162, 165, 168, 179) concluded that the effects of silver
} 
or-less exogenous political events that created silver risk - the 1878 Bland-Allison Act, the 1890

Sherman Silver Purchase Act - occurred years before the crises in question.

\section{3) Monetary shocks from agriculture}

The quantity of a crop that is harvested varies greatly from year to year. Some harvest fluctuations may be endogenous responses to macroeconomic conditions, but agricultural output is also uniquely affected by obviously exogenous factors: weather and pests. Scholars have considered two possible channels from harvest fluctuations to pre-1914 American financial crises. The first runs through high-powered money demand. America's three great staple crops, cotton, corn and wheat, were planted in or before the spring and harvested within a span of months from late summer through autumn - the harvest season. ${ }^{10}$ Farmers were paid for their crops, and farmworkers received most of their wages, during or shortly after the harvest, creating a surge in demand for cash which fell off gradually to a low in early summer. The surge was accommodated by cash shipments from the northeast, funded largely by withdrawals of bankers' balances from New York (Sprague, 1903; Kemmerer, 1910). Chari (1989) speculates that American financial crises occurred in years when agricultural conditions created especially large surges in cash demand and withdrawals of banks' balances, leaving New York banks vulnerable to further shocks. To test this, Calomiris and Gorton (1991) look for a relation between harvest size and occurrence of crises, on the assumption that rural cash demand was positively related to crop production. They conclude "seasonal money-demand shocks originating in the countryside cannot possibly be the cause of panics" (p. 148), as they find "years in which panics occurred in the fall... were not years of unusually large harvests for corn, wheat and cotton" (p. 137).

risk came into play after the financial crisis was already underway. Fels (1959, pp. 184-187) describes silver risk as a factor that interacted with the cyclical downturn, but did not cause it.

${ }^{10}$ Cotton was planted from March through May, harvested from August through November (Covert 1912, p. 93). In the 1900s, over 60 percent of the harvest was completed by the end of October (U.S. Bureau of the Census 1909, p. 13). Wheat was planted in two seasons: "winter wheat" from September through October, "spring wheat" from March through May. Both plantings were harvested and threshed in late summer and early autumn; corn was planted in the spring, harvested from early September through November (Covert 1912, pp. 17, 30, 41; U.S. Department of Agriculture, Monthly Crop 
A second possible channel runs through revenues from crop exports and the potential link between net exports and the money supply. Under the gold standard, for most countries the sum of net exports, international capital inflow and foreign investment income was balanced by an inflow of monetary gold from other countries. In the U.S., the supply of high-powered money to banks and the public consisted of monetary gold plus currency (greenbacks, silver notes, national banknotes, silver coins) minus money held in U.S. Treasury vaults (Friedman and Schwartz 1963, pp. 124-134). Currency growth was unresponsive to economic conditions and mostly out of the Treasury's control. ${ }^{11}$ On occasion, Treasury officials deliberately managed their reserves of vault cash to affect the money supply (Timberlake, 1978) but these operations were limited by the degree of slack between expenditures, tax receipts and bond operations. The Treasury did not generally sterilize international gold flows. Thus, the change in the American high-powered money supply was linked to export revenue, as an element in the balance of payments.

Cotton and wheat (raw wheat and wheat flour) were important American exports. For both crops, export revenue was positively related to the size of the harvest, and export-revenue fluctuations were large relative to the high-powered money supply (Davis, Hanes and Rhode 2009). Thus, fluctuations in cotton or wheat harvests could produce substantial exogenous shocks to potential highpowered money supply growth. Contemporaries believed cotton and wheat harvests affected financial conditions through this channel (Sprague, 1903, p. 50; Andrew 1906). Note it implies unusually large harvests of cotton or wheat would tend to reduce, not raise the probability of a financial crisis.

Friedman and Schwartz (1963) argue that the crisis of 1893 was triggered by fluctuations in wheat harvests through this money-supply channel and the classic specie-flow mechanism. Wheat and wheat-flour export revenue was extraordinarily high following the harvest of autumn 1891, partly

Reporter, Sept.1920, p. 100).

${ }^{11}$ The greenback supply was fixed. The rate of silver note creation was governed by longstanding political factors. The rate of national banknote creation was insensitive to variations in interest rates and business activity (Myers, 1931, pp. 396-98, 402-03; Cagan, 1965, p. 91). 
because of a large harvest, an "accident of weather" (p. 107). The resulting gold inflow "fostered a spurt in the stock of money from 1891 to $1892 "$ that interrupted a longer-term deflationary trend. A reversion to deflation in 1893 caused bank runs because "[1]oans that would have been good and banks that would have been solvent if prices had been stable or rising became bad loans and insolvent banks under the pressure of price deflation" (p. 108). Wheat export revenues remained low until "another one of those fortuitous combinations of good harvests at home and poor harvests abroad" in 1897, which contributed to recovery from the 1896 crisis (p. 140). ${ }^{12}$

Davis, Hanes and Rhode (DHR) (2009) examine the relation between pre-1914 American business cycles and harvests of all three of America's staple crops, cotton, wheat, and corn, constructing instruments for harvest fluctuations from weather data. DHR find that, within 1879-1913, the size of the cotton harvest had positive effects on the following year's industrial production, gold inflows, and high-powered money-supply growth, and negative effects on commercial-paper interest rates. Wheat harvests had positive effects on gold inflow and money growth but no apparent effects on industrial production or interest rates. Corn harvests affected none of these variables. With respect to cotton, DHR find no systematic differences between OLS and IV coefficient estimates, and no evidence of reverse causality from business cycles to harvest fluctuations. Thus, it appears cotton harvest fluctuations in general, not just those due to weather, were exogenous to the macroeconomy.

DHR argue that a crop's macroeconomic effects reflected the relative intensity of its more immediate effects on export revenue and rural cash demand. To the degree that a bumper harvest boosted export revenue, it drew in gold, lowered interest rates and stimulated real activity. To the degree that a harvest boosted cash demand, it drew in gold but raised interest rates and depressed real activity. Corn harvests had no apparent macroeconomic effects because they had little effect on export revenue or cash demand: little corn (or corn meal) was exported; relatively little was even sold off the

\footnotetext{
12 See also Fels (1959, pp. 60, 181), Conant (1909, p. 673).
} 
farm for cash income. Wheat harvests had strong positive effects on export revenue and cash demand, so wheat affected gold flows but not, on net, interest rates and real activity. Cotton harvests had strong effects on export revenue, but, unlike wheat, relatively weak effects on cash demand. Thus, a big cotton harvest lowered interest rates and raised industrial production. Cotton's export-revenue effect was relatively strong partly because cotton exports were a large share of domestic production: export revenue was very large relative to farmers' income from sales of the crop. For wheat, exports (in the form of wheat and wheat flour) were a smaller share of production, so export revenue was smaller relative to crop sales. It is also possible, DHR argue, that cotton's cash-demand effect was relatively weak because Southern agricultural institutions tended to substitute merchants' and landlords' credit for cash balances (pp. 1682-1686, 1708-1711).

DHR do not examine the relation between harvests and financial crises. In this article, we take on that task.

Figures 4 and 5 plot fluctuations in wheat and cotton harvests and export revenues. The top line in each figure is the deviation from a quadratic time trend (over 1869-1913 to match results we will present below) in the log of a year's autumn harvest, in bushels or bales. The lower line is the deviation from a similar quadratic time trend in "real" revenue from exports of each crop (cotton or wheat and wheat flour). ${ }^{13}$

From the figures, it is obvious that harvest fluctuations were just one factor affecting crop export revenue. Wheat revenue was high in 1907 despite a poor harvest. Cotton revenue was low in 1898 and 1908 despite big harvests. Some of the other factors affecting export revenue must have been endogenous to macroeconomic conditions: e.g. industrial demand for raw materials. Thus, we do not

\footnotetext{
${ }^{13}$ Product-specific export revenues are available for twelve-month spans ending June. Export revenue associated with a year's harvest is that for the span ending June of the following year. We deflate nominal revenue by the era's standard monthly wholesale price index (Warren and Pearson index linked to BLS) averaged over the twelve months ending June of the harvest year, not averaged over the harvest year itself : the WPI puts heavy weight on cotton and wheat prices, which were obviously affected by harvests and export demand; cotton harvests in particular affected prices of industrial products, consistent with cotton's effects on industrial production (Davis, Hanes and Rhode, 2009).
} 
argue that export-revenue fluctuations in general were exogenous shocks to the macroeconomy. Our focus is on export-revenue fluctuations due to harvest fluctuations.

Recall Friedman and Schwartz attribute the crisis of 1893 to a drop-off in wheat export revenue after 1891. That drop-off is apparent in Figure 4. It is clearly due, at least partly, to a decrease in the size of the American harvest. But Figure 5 shows something Friedman and Schwartz missed. The lower line of Figure 5 indicates that the cotton harvest prior to 1893, that is the harvest of autumn 1892, generated extremely low export revenue. The harvests prior to 1884 and 1896 also generated extremely low export revenue. The two crises that can be accounted for as the result of sudden stops, 1890 and 1907, were different: neither was preceded by a cotton harvest that generated low export revenue. The crisis of November 1890 was coincident with a cotton harvest that generated extremely high export revenue. The upper line of Figure 5 shows that the low cotton revenues of 1883, 1893 and 1896 were all associated with poor harvests. The high revenue of 1890 was associated with a bumper crop. Importantly, according to contemporaries the poor harvests of 1883,1892 and 1895 and the good harvest of 1890 were all due to the exogenous factors of pests and weather. ${ }^{14}$

To check whether the relation between financial crises and cotton harvest fluctuations apparent in Figure 5 holds for wheat as well, we ran a probit regression with the left-hand side variable equal to one in years with crises, and the previous years' cotton and wheat harvest fluctuations (as in the figures) on the right-hand side, over 1879-1913 (harvests of 1878-1912). To account for the foreign financial shocks of 1890 and 1907 we removed those years from the sample. ${ }^{15}$ The coefficient on cotton is negative and significantly different from zero at the five percent level; the wheat coefficient is much smaller and far from significance:

\footnotetext{
14 1883: uneven seasonal rainfall and a summer drought (US Commissioner of Agriculture 1883, pp. 414-415, 422). 1892: an enormous flood in the lower Mississippi valley, as well as insect depredations (US Secretary of Agriculture 1892, p. 413). 1895: drought and bollworm (Monthly Report of the USDA Statistician, Sept. 1895 p. 2; Nov. 1895 p. 3 ). The 1890 crop benefited from "fine weather"; it was "very free from rust, and free from worms" (Monthly Report of the USDA Statistician, July 1890, pp. 331-32). "The plants were prolific in bolling, opening so rapidly in the early autumn as the tax the capacity of pickers" (January and February 1891, p. 21).

${ }^{15}$ For econometric reasons, in a probit it is not possible to use dummy variables for such a purpose (Caudill, 1987).
} 
Probability of Crisis $=-2.17-10.92$ Cotton harvest -1.09 Wheat harvest $\quad \mathrm{N}=33$

SE [5.34] [4.11] Pseudo-R2=0.37

\section{3) Harvests and financial conditions: hypotheses}

We argue that the crises of 1884,1893 and 1896 were triggered by poor cotton harvests in 1883, 1892 and 1895. Also, the bumper cotton harvest and export revenues of 1890 may be largely responsible for the absence of a cyclical downturn and widespread bank failures in the U.S. in the wake of the Barings crisis. The channel from cotton harvest fluctuations to financial conditions runs through the balance of the crop's effects on export revenue versus rural cash demand. Because cotton's export-revenue effect was relatively strong, a poor cotton harvest tended to create conditions that endangered the solvency of New York banks: a decline in stock prices and a cyclical downturn, at a time when deposits were already being withdrawn.

We make this argument in two stages. In this section we hypothesize effects of harvest fluctuations on financial markets and real activity through export revenue and cash demand. To do this, we model key features of the pre-1914 American economy with a set of equations. Our hypothesis is about conditions that could set off a crisis, not about conditions during a crisis which were peculiar in many ways, so the equations are not meant to describe the operation of financial markets under ordinary, not crisis conditions. Using the equations we lay out implications for observable variables including New York bank deposits, stock prices and industrial production. In the next section, we will test the implications against data.

Our equations are log-approximations, with constants omitted. Real variables are log-deviations from long-term trends.

\section{1) Money-supply growth, the balance of payments and the current account}

Under the gold standard the change in the real money supply across a span of time was:

(1) $\Delta(m-p)=g+z-\Delta p=k a+c a+z-\Delta p$ 
where $g$ is the inflow of monetary gold expressed as a fraction of the previous period's high-powered money supply. $k a$ and $c a$ are real values of net capital inflow and the current account, scaled by the average magnitude of their fluctuations relative to trend money growth (to simplify notation). $z$ represents the effect of other money-supply determinants such as changes in the nongold currency supply and Treasury vault cash.

The current account - net exports less the net outflow of factor payments and transfers - might be affected by fluctuations in real activity through demand for imports, and by the relative price of foreign goods. The latter depends on exchange rates, the domestic nonagricultural price level and the foreign price level. But the key exchange rate, against sterling, did not vary enough to make a substantial difference to the relative price of foreign goods. ${ }^{16}$ Thus:

$$
c a=-\alpha y-\varphi\left(p-p^{*}\right)+\varepsilon^{C A}
$$

where $y$ is nonagricultural real activity, as indicated by fluctuations in IP. $p$ is the domestic price level. $p^{*}$ is the foreign price level. $\varepsilon^{C A}$ represents exogenous shocks affecting the current account, such as shocks to export revenue.

\section{2) The capital account and imperfect capital mobility}

The capital account reflects the change in net international demand for a country's assets. International demand for American assets must have been sensitive to returns on American versus European assets. Europeans traded American stocks and bonds in European markets as well as New

York, with rapid arbitrage across the Atlantic. There was also arbitrage at the shorter maturity of bills. London was the central bill market of Europe. ${ }^{17}$ Americans financing security portfolios shifted between London finance bills and New York time money depending on relative interest rates and

\footnotetext{
${ }^{16}$ Most international payments were settled through claims to sterling in London even if the counterparty was outside the British Empire (Goodhart, 1969, pp. 53-55). The London-New York exchange rate remained within one percent of parity throughout the era (Canjels, Prakash-Canjels and Taylor, 2004, p. 870).

${ }^{17}$ Bill rates in continental financial centers were tightly linked to London's, less tightly linked across continental centers (Bordo and MacDonald, 2005).
} 
expected exchange rates (Morgenstern, 1959, p. 527). Some firms borrowed in London through finance bills to lend time money in New York (Margraff, 1912, p. 41). Arbitrage between London bills and matching maturities in New York also operated through the mechanics of foreign exchange (Goodhart, 1969). Except at times when perceived silver risk was high, expected future changes in the exchange rate were small relative to variations in interest rates. Thus, international arbitrage tended to equalize both bill-maturity interest rates and expected returns to long-term securities between New York and European financial centers, especially London.

Within New York, commercial paper was a very close substitute for time money, from a lender's point of view. Unlike today, there was no active secondary commercial-paper market, so commercial paper was about as illiquid as time-money loans. Thus, changes in New York commercial paper rates were highly correlated with changes in time-money rates. ${ }^{18}$ Commercial paper was distributed throughout the U.S. by national dealers. Outside New York it was the only available shortterm open-market investment. For a hinterland bank, commercial paper rates were the opportunity cost of short-term loans to local borrowers. Through commercial paper, therefore, short-term interest rates across the U.S. were linked to New York rates, and therefore European rates.

However, there is no reason to believe international arbitrage was sufficient to equalize expected returns in the U.S. and Europe, to the extreme of perfect capital mobility. European investors did not viewed American and European assets as perfect substitutes: in London realized risk-adjusted rates of return were consistently higher for American securities even after the diminution of silver risk in 1896 (Edelstein, 1982, pp. 157-58). Many empirical studies have rejected the hypothesis that uncovered interest-rate parity (UIP) held between London bills and New York time money or

\footnotetext{
${ }^{18}$ Monthly series on New York commercial paper rates are available throughout the gold-standard era. Regular series on New York time money rates are unavailable until 1890. We calculated quarterly average values of Macaulay's monthly series for 90-day time money rates. In a sample from 1890 through 1913, the correlation between quarter-to-quarter changes in the New York commercial paper rate and the time money rate is 0.89 , excluding years with financial crises. According to Macaulay (1938, p. A345), fragmentary data indicate time money rates were also tightly linked to commercial paper rates before 1890 .
} 
commercial paper. ${ }^{19}$ Thus, we describe international capital inflow as in models of "imperfect" international capital mobility (e.g. Kouri and Porter, 1974):

(3) $k a=\gamma \Delta\left(i-i^{*}-\varepsilon^{E e}\right)-\varepsilon^{K A}$

where $i$ is the expected short-term return to American assets directly or indirectly subject to international arbitrage, including time money and commercial paper. $i *$ corresponds most obviously to open-market bill rates in London, the central financial market of Europe. ${ }^{20} \varepsilon^{E e}$ is the expected increase in the New York price of London sterling. Changes in $\varepsilon^{E e}$ reflect fluctuations in perceived silver risk, and any predictable exchange-rate movements within the gold points; the latter were large enough to affect relative asset returns if not trade. ${ }^{21} \varepsilon^{K A}$ accounts for any other factors that might affect demand for American assets.

\section{3) Demand for high-powered money}

As $i$ in (3) was linked to commercial paper rates, it would be related to demand for highpowered money and New York bank deposits. Aggregates of deposits and cash held by the public for the pre-1914 era show a normal money-demand relation to interest rates and national income or wealth (Friedman and Schwartz, 1982). For a bank outside New York, the commercial paper rate was the opportunity cost of holding New York bankers' balances. New York banks paid interest on bankers' balances, but they held the rate nearly fixed across the pre-1914 era (James, 1978, pp. 176, 265-67). Out-of-town banks held bankers' balances in New York partly to satisfy regulatory reserve requirements, but bankers' balances were usually far in excess of requirements and varied substantially from quarter to quarter (Myers, 1931, pp. 237-39; Goodhart, 1969, p. 76-77). Thus, we describe New York deposits as:

\footnotetext{
${ }^{19}$ Giovannini (1993, pp. 133-136), Foster (1994). Studies of the covered differential find that covered interest-rate parity also failed to hold at business-cycle frequencies (Obstfeld and Taylor 1998, pp. 361-363; Juhl, Miles and Weidenmier, 2005). "Clearly, interest rate parity did not hold perfectly across the Atlantic" (Calomiris and Hubbard, 1996, p. 195).

${ }^{20}$ London was central in the sense that bill rates in continental financial centers were tightly linked to London's, less tightly linked from one continental center to another (Bordo and MacDonald, 2005).
} 


$$
d-p=\kappa y-\delta i+\varepsilon^{d}
$$

High-powered money was the sum of cash reserves held by New York banks, and cash held by the public and out-of-town banks. New York banks' reserve-deposit ratio is:

$$
r-d=-\rho i+\varepsilon^{r} \quad \text { where } \rho \geq 0
$$

Cash held by the public and out-of-town banks is:

$$
c-p=\lambda y-\theta i+\varepsilon^{c}
$$

Letting $\sigma$ denote the long-run average share of New York banks' cash reserves in total high-powered money, the quantity demanded of high-powered money demand is:

$$
m-p=\mu y-v i+\varepsilon^{m d}=\sigma r+(1-\sigma) c-p
$$

$$
\text { where } \mu=\sigma \kappa+(1-\sigma) \lambda \quad v=\sigma(\delta+\rho)+(1-\sigma) \theta \quad \varepsilon^{m d}=\sigma\left(\varepsilon^{r}+\varepsilon^{d}\right)+(1-\sigma) \varepsilon^{c}
$$

Shocks to the public's demand for cash are reflected in $\varepsilon^{c}$, hence in $\varepsilon^{m d}$.

Equating demand and supply of high-powered money defines a relation between $i$, moneydemand shocks and balance-of-payments factors:

$$
\begin{aligned}
& \Delta i=-\beta_{1}\left[\varepsilon^{C A}-\Delta \varepsilon^{m d}-\gamma \Delta\left(i^{*}+\varepsilon^{E e}\right)-\varepsilon^{K A}+\varphi p^{*}+z-(\alpha+\mu) y-(1+\varphi) p+\mu y_{-1}+p_{-1}\right] \\
& \text { where } \beta_{1}=1 /(\gamma+v)
\end{aligned}
$$

\section{4) Interest rates, output and the price level}

Relations between interest rates, the price level and real activity were governed by a constraint on long-run trend inflation imposed by the gold standard. For all gold-standard countries, trend inflation was largely determined by the balance between world gold production, growth in real output and financial innovations in the use of monetary gold. There was little, if any, serial correlation in inflation from year to year. Judging from the behavior of interest rates, expected inflation at both long

\footnotetext{
${ }^{21}$ Certainly, international investors took account of regular seasonal movements in exchange rates (Myers, 1931, p. 345).
} 
and short horizons was always close to zero and remarkably unresponsive to economic events (Barsky, 1987; Barsky and Delong, 1991; Bordo and Dewald, 2001).

Under stable trend inflation, an expectations-augmented Phillips curve of either the oldKeynesian or New-Keynesian variety implies a positive relation between inflation and output along the lines of the original Phillips curve, rather than the "accelerationist" Phillips curve of the postwar era (Alogoskoufis and Smith, 1991, Hanes and James, 2011). This is indeed observed in empirical studies of the pre-1914 era (Gordon, 1990, Hanes, 1999). Thus:

(9) $\Delta p=\xi y+\varepsilon^{p}$

where $\varepsilon^{p}$ would account for any extraordinary changes in inflation expectations, as well as other types of supply shock.

Also, a positive shock to nominal interest rates would raise real interest rates and reduce real spending. Empirical studies of postwar data generally find that an exogenous shock to interest rates affects real spending and output after about six months, with the strongest effect appearing after about a year (e.g. Christiano, Eichenbaum and Evans, 2005). We are aware of no evidence that the lag was shorter in pre-1914 America. Thus, we assume a change in interest rates would affect real activity with a lag:

(10) $\Delta y=-\tau \Delta i_{-1}-\eta \Delta\left(p-p^{*}\right)+\varepsilon^{I S}$

where a period is, in this context, about six months. Consistent with (2) we also allow for an effect of the relative American price level on the volume of spending directed to domestic output (and foreign demand for exports). $\varepsilon^{I S}$ accounts for other determinants of real spending, such as exceptions to the usual pattern for expected inflation which would affect the relation between nominal and real interest rates, and extraordinary disturbances to the operation of financial intermediaries which would affect the supply of credit to potential borrowers (Woodford, 2010). 
Unlike real activity, American securities prices should be immediately affected by changes in $i$. As stocks and bonds were subject to direct international arbitrage, $i$ corresponds not only to timemoney or commercial paper rates, but also to required short-term returns to securities. Conceivably, financial market participants would forecast the effect of a change in $i$ on future real activity. That would magnify the immediate effect of a change in $i$ on stock prices by changing expectations of future corporate earnings, and on bond prices by changing perceived probabilities of future defaults. In any case, a realized change in $y$ could affect securities' prices as it was associated with changes in expected earnings and defaults. Thus:

\section{(11) $\Delta p^{S, B}=-\psi^{S, B} \Delta i+\chi^{S, B} \Delta y+\Delta p+\varepsilon^{S, B}$}

where $p^{S}$ is the level of American stock prices, $p^{B}$ is the level of bond prices, and the coefficients and disturbance terms differ for stocks and bonds. The disturbance terms account for, among other things, deviations from the usual relation between expectations and current levels of $i$ and $y$.

Call money was not subject to direct international arbitrage. There are many contemporary references to American borrowing from London at the maturity of time money but we have found no references to trans-Atlantic lending at the overnight maturity. A link between New York call money rates and $i$ would come through time money or commercial paper. Generally, one would expect rates for these bill-maturity assets to equal the expected return to call-money lending over the appropriate horizon plus a liquidity premium. Descriptions of the call-money market by contemporaries (e.g. Woodlock, 1908; White, 1910) and later observers (Myers, 1930, pp. 265-287; Goodhart, 1969) suggest the premium varied a lot and depended on a distinct supply and demand for call-money funds. Borrowers attempted to finance a fairly stable fraction of their portfolios' value with call money. They were reluctant to substitute call-money for time-money even when call money rates were especially low, for fear they would be unable to roll over the loans (Woodlock, 1908, p. 29). Thus, an increase in American securities' prices raised the demand for call money loans as it raised the value of borrowers' portfolios and collateral. On the supply side, the bulk of call-money lending was by New York banks, 
which usually tried to match their holdings of this low-return but uniquely liquid asset to the volume of bankers' balances, a volatile liability. The supply of call money increased with the volume of bankers' balances. According to Myers (1930, p. 275):

call money rates may be high under two conditions: when a rapid drain of funds to the interior has reduced the surplus funds of New York banks and caused a reduction in the amount of their loans on call; or when a rising movement of security prices increases the demand for call loans...Call rates might be low under the two opposite conditions; when there is a large volume of surplus funds in the market under circumstances which make it inadvisable to invest them otherwise than at call, or when the security market is so sluggish that it does not require even the small amount of funds available.

A study of call-money liquidity premiums with proper accounting for the details of interest-rate definitions, timing and causality is beyond the scope of this paper. But the relation between call money rates, securities' prices and New York deposits posited by Myers is obvious in our data. ${ }^{22}$ Thus we allow for the possibility that the difference between the call-money rate and $i$ was positively related to stock and bond prices, negatively related to deposits in New York banks:

(12) $i^{\text {call }}=i+\omega^{S} p^{S}+\omega^{B} p^{B}-\zeta d+\varepsilon^{\text {call }}$

\section{5) Effects of harvest fluctuations}

To the degree that an exogenous harvest fluctuation is a shock to export revenue, it affects $\varepsilon^{C A}$. To the degree that a harvest fluctuation affects demand for cash and hence high-powered money, it

${ }^{22}$ Using quarterly average values from 1879-1913, excluding quarters in years containing crises (119 observations), we regressed the quarter-to-quarter change in the call-money rate, and the change in the call money rate minus the commercial paper rate, on the change in the log of the stock price index, the change in NYCH deposits and quarterly dummies. Either way, coefficients on the stock price index were positive, coefficients on NYCH deposits were negative, and both were significantly different from zero at conventional levels:

$\Delta \mathrm{i}$ call $=-0.86+11.13 \Delta \mathrm{Ln}($ Stock Index $)-14.98 \Delta \operatorname{Ln}(\mathrm{NYCH}$ deposits $) \quad R 2=0.46$

SE [0.37] [3.07] [3.19]

Dummies: 0.62 Q2 $1.02 \mathrm{Q} 3 \quad 1.89 \mathrm{Q} 4$

$[0.63] \quad[0.45] \quad[0.55]$

$\Delta\left(\mathrm{i}^{\text {call }}\right.$ - i $)=-0.70+9.61 \Delta \operatorname{Ln}($ Stock Index $)-6.58 \Delta \operatorname{Ln}(\mathrm{NYCH}$ deposits $) \quad R 2=0.31$

SE [0.35] [3.33] [3.00]

Dummies: $0.58 \mathrm{Q} 2 \quad 0.28 \mathrm{Q} 3 \quad 1.65 \mathrm{Q} 4$

$[0.43] \quad[0.42] \quad[0.52]$ 
affects $\varepsilon^{m d}$ (from $\varepsilon^{c}$ ). We would not rule out the possibility that harvest fluctuations affected factors reflected in other $\varepsilon$ terms. For example, harvest fluctuations may have affected the public's expectations of future output, inflation and exchange rates, which would mean changes in $\varepsilon^{I S}, \varepsilon^{p}$ and $\varepsilon^{E e}$. As noted above, some contemporaries had a notion that harvest fluctuations affected financial conditions. But we have found no evidence of a general understanding of the relation between harvests, business cycles and inflation, or of a potential difference between cotton and wheat. ${ }^{23}$ Certainly, there is no evidence that American harvests had an immediate effect on the foreign interest rate $i^{*}$, foreign macroeconomic conditions, or changes in $z$ due to Treasury activities. DHR (2009b) look for and do not find a relation between American harvest fluctuations, on the one hand, and nongold determinants of the American money supply, London bill rates or British real activity on the other. Thus, we consider only the effects of harvest-related disturbances to $\varepsilon^{C A}$ and $\varepsilon^{m d}$ holding fixed the other $\varepsilon^{\prime} \mathrm{s}, i^{*}, z$ and the foreign price level $p^{*}$.

Disturbances to $\varepsilon^{C A}$ and $\varepsilon^{m d}$ affect other variables through (8). With output and the price level predetermined (because of the lag in 10), (8) gives the change in $i$ from the previous period. A change in $i$ affects the following period's $y$ and $p$ through (9) and (10). Given $i, y$ and $p,(4),(11)$ and (12) determine New York deposits $d$, stock prices $s$ and the call-money rate $i^{\text {call }}$.

A poor harvest of an export crop means a low value of $\varepsilon^{C A}$ in a period. In (8), that tends to raise the required return to American assets $i$. A poor harvest can also mean a decrease in $\varepsilon^{m d}$ from the

\footnotetext{
${ }^{23}$ A plausible possibility is an effect on exchange-rate expectations through a harvest's effect on gold flows. As international gold shipments meant the exchange rate was at or near a gold point, a gold inflow (outflow) over a period tended to raise (lower) the average foreign exchange value of the dollar over the period. Under the gold standard exchange rates were usually expected to revert toward parity if they did not remain at the current level. Thus, a gold inflow (outflow) could be associated with an increase (decrease) in $\varepsilon^{E e}$. DHR (2009b) show that allowing for this effect makes no substantial difference to our hypothesized effects on interest rates and output.
} 
previous period. In (8), a negative value of $\Delta \varepsilon^{m d}$ tends to lower $i$. The net effect on financial conditions depends on the balance $\left(\varepsilon^{C A}-\Delta \varepsilon^{m d}\right)$. For a crop with a relatively strong effect on export revenue, a poor harvest means a decrease in $\left(\varepsilon^{C A}-\Delta \varepsilon^{m d}\right)$.

The timing of harvest-related shocks is important. Foreign payments for cotton and wheat exports began within the autumn harvest season and continued through the early months of the following year (Kemmerer, 1910, pp. 136-140). Taking a period to be about six months and letting $h$ denote exogenous fluctuations in a crop's harvest, the export-revenue effect of a harvest fluctuation is a disturbance $\partial \varepsilon^{C A} / \partial h>0$ that occurs within one period - period 1. Another period - period 2 - passes before the next harvest season. The money-demand disturbance $\partial \varepsilon^{m d} / \partial h$ occurs within period 1 and persists through period 2. (Allowing the money-demand disturbance to vary across the two periods complicates the notation without adding anything to our argument.)

Let $\left(x_{1}-x_{0}\right)$ denote the change in a variable to the harvest period from period 0 prior to the harvest. Within the harvest period 1 the size of the harvest does not affect industrial activity, but it may affect other variables depending on the balance of $\partial \varepsilon^{C A} / \partial h$ against $\partial \varepsilon^{m d} / \partial h$ :

$$
\begin{aligned}
& \text { (13) } \partial\left(i_{1}-i_{0}\right) / \partial h=-\beta_{1}\left[\partial \varepsilon^{C A} / \partial h-\partial \varepsilon^{m d} / \partial h\right] \\
& \text { (14) } \partial\left(d_{1}-d_{0}\right) / \partial h=\delta \beta_{1}\left[\partial \varepsilon^{C A} / \partial h-\partial \varepsilon^{m d} / \partial h\right]=-\delta \partial\left(i_{1}-i_{0}\right) / \partial h \\
& \text { (15) } \partial\left(p_{1}^{S, B}-p_{0}^{S, B}\right) / \partial h=\psi^{S, B} \beta_{1}\left[\partial \varepsilon^{C A} / \partial h-\partial \varepsilon^{m d} / \partial h\right] \\
& \text { (16) } \partial\left(i_{1}{ }^{\text {call }}-i_{0}{ }^{\text {call }}\right) / \partial h=-\left(1+\zeta \delta-\omega^{S} \psi^{S}-\omega^{B} \psi^{, B}\right) \beta_{1}\left[\partial \varepsilon^{C A} / \partial h-\partial \varepsilon^{m d} / \partial h\right]
\end{aligned}
$$

An export crop fluctuation can have an immediate negative effect on commercial-paper or time-money rates and immediate positive effects on New York deposits, stock or bond prices. Its effect on callmoney rates is ambiguous, because its positive effects on securities' prices tends to raise the callmoney rate relative to bill-maturity rates. 
In the post-harvest period 2, a harvest fluctuation that affected financial conditions in the harvest period affects industrial activity as well as financial variables:

(17) $\partial\left(y_{2}-y_{0}\right) / \partial h=\beta_{2} \beta_{1}\left[\partial \varepsilon^{C A} / \partial h-\partial \varepsilon^{m d} / \partial h\right]=-\beta_{2} \partial\left(i_{1}-i_{0}\right) / \partial h \quad$ where $\beta_{2}=\tau /(1+\eta \xi)$

(18) $\left.\partial\left(i_{2}-i_{0}\right) / \partial h=-\left(1-\beta_{1} \beta_{2} \beta_{3}\right) \beta_{1}\left[\partial \varepsilon^{C A} / \partial h-\partial \varepsilon^{m d} / \partial h\right]=\left(1-\beta_{1} \beta_{2} \beta_{3}\right)\right) \partial\left(i_{1}-i_{0}\right) / \partial h$

where $\beta_{3}=(1+\varphi) \xi+\alpha+\mu$

(19) $\partial\left(d_{2}-d_{0}\right) / \partial h=\left[\delta\left(1-\beta_{1} \beta_{2} \beta_{3}\right)+(\kappa+\xi) \beta_{2}\right] \beta_{1}\left[\partial \varepsilon^{C A} / \partial h-\partial \varepsilon^{m d} / \partial h\right]$

$$
=\left[\left(1-\beta_{1} \beta_{2} \beta_{3}\right)+(\kappa+\xi) \beta_{2}(1 / \delta)\right] \partial\left(d_{1}-d_{0}\right) / \partial h
$$

$$
\partial\left(p_{2}^{S, B}-p_{0}^{S, B}\right) / \partial h=\left[\left(\xi+\chi^{S, B}\right) \beta_{2}+\psi^{S, B}\left(1-\beta_{1} \beta_{2} \beta_{3}\right)\right] \beta_{1}\left[\partial \varepsilon^{C A} / \partial h-\partial \varepsilon^{m d} / \partial h\right]
$$

(21) $\partial\left(i_{2}{ }^{\text {call }}-i_{0}{ }^{\text {call }}\right) / \partial h=$

$$
\left[-\left(1+\zeta \delta-\omega^{S} \psi^{S}-\omega^{B} \psi^{B}\right)\left(1-\beta_{1} \beta_{2} \beta_{3}\right)+\left(\left(\omega^{S+\omega^{B}}\right)(\xi+\chi)+(\kappa+\xi)\right) \beta_{2}\right] \beta_{1}\left[\partial \varepsilon^{C A} / \partial h-\partial \varepsilon^{m d} / \partial h\right]
$$

The harvest's effect on commercial paper rates may diminish (because an increase in output tends to reduce net exports and boost high-powered money demand). Its effect on New York deposits and stock prices is less likely to diminish and may increase, reflecting the change in real activity. Its effect on call-money rates is again ambiguous.

Through these channels, a poor harvest of an export crop could create the conditions for a financial crisis - low deposits in New York banks, a drop in stock prices and a cyclical downturn - in the post-harvest period. The occurrence of a financial crisis could be associated with many more disturbances such as a decrease in $\varepsilon^{d}$, an increase in $\varepsilon^{r}$, a decrease in $\varepsilon^{I S}$ or an increase in $\varepsilon^{E e}$ due to heightened silver risk. Most of these disturbances would reinforce the effects described by (13)-(21). But these effects should appear prior to the occurrence of a financial crisis and whether or not a crisis ensues.

An export crop's harvest fluctuations may fail to affect financial conditions and industrial 
activity if $\left(\partial \varepsilon^{C A} / \partial h-\partial \varepsilon^{m d} / \partial h\right)$ is about equal to zero. But whether or not an export crop's harvest affects financial conditions, it will affect international gold flows:

$$
\begin{gathered}
\partial g_{1} / \partial h=\partial\left(m_{1}-m_{0}\right) / \partial h=v \beta_{1}\left[\partial \varepsilon^{C A} / \partial h-\partial \varepsilon^{m d} / \partial h\right]+\partial \varepsilon^{m d} / \partial h \\
\partial\left(g_{1}+g_{2}\right) / \partial h=\partial\left(m_{2}-m_{0}\right) / \partial h=\left[\beta_{2}(\xi+\mu)+v\left(1-\beta_{1} \beta_{2} \beta_{3}\right)\right] \beta_{1}\left[\partial \varepsilon^{C A} / \partial h-\partial \varepsilon^{m d} / \partial h\right]+\partial \varepsilon^{m d} / \partial h
\end{gathered}
$$

where $\left(g_{1}+g_{2}\right)$ is cumulative gold inflow since the pre-harvest period.

Our hypothesis is that, for wheat, $\left(\partial \varepsilon^{C A} / \partial h-\partial \varepsilon^{m d} / \partial h\right)$ was about equal to zero. Thus, the wheat harvest affected gold flows but not financial markets or real activity. For cotton, $\left(\partial \varepsilon^{C A} / \partial h-\partial \varepsilon^{m d} / \partial h\right)$ was positive. Thus, the cotton harvest affected financial markets within the harvest period and real activity subsequently. A poor cotton harvest created all the conditions for a financial crisis - low deposits in New York banks, a drop in stock prices and a cyclical downturn - by the post-harvest period.

\section{6) Interaction between cotton harvests and foreign financial conditions}

Returning to (8), observe that two variables in the expression are the foreign interest rate $i *$ and the international asset-demand shock $\varepsilon^{K A}$. An increase in foreign interest rates due to tightening by foreign central banks corresponds to an increase in $i^{*}$. A decrease in foreign demand for American assets due to fire sales by European investors in an event such as the Barings' crisis corresponds to an increase in $\varepsilon^{K A}$. Thus, the model implies that a sudden stop of foreign investment, as in 1890 and 1907, has the same effect as a bad cotton harvest. By the same token, as a bumper cotton harvest

means a large value of $\left(\partial \varepsilon^{C A}-\partial \varepsilon^{m d}\right)$, it would tend to counteract the financial and macroeconomic effects of interest-rate hikes or other financial disturbances in Europe.

\section{7) What if America had a central bank?}

If America had a central bank, its open-market operations and discounting would affect $z$ 
in (1) as they affected the supply of nongold high-powered money - not only currency, but also financial institutions' balances at the central-bank. Thus, a central bank could adjust $z$ in response to cotton harvests. From (8), one can see that an American central bank could have counteracted the financial effects of cotton harvest fluctuations by ensuring that $\partial z / \partial h=-\partial \varepsilon^{C A} / \partial h+\partial \varepsilon^{m d} / \partial h$. A central bank could achieve this by buying (selling) domestic securities in response to a poor (abundant) harvest, or simply by setting its discount rate slightly above the normal market rate for the season. Cotton harvests would then, like wheat harvests, affect international gold flow but not financial markets or real activity.

\section{4) Harvests and financial conditions: econometric analysis}

We examine harvests' actual effects on financial markets by regressing changes in observable variables on deviations from trend in the size of the cotton, wheat, and corn harvests. Estimated coefficients show how effects played out over time across the harvest season and through the following calendar year. As our hypotheses mainly have to do with the operation of financial markets outside crises, we repeat all regressions on samples excluding harvests that took place within the calendar year containing a crisis (autumn 1884, 1890, and so on). To ensure that the apparent effects of cotton harvests held whether or not a crisis occurred in the following year, we also run regressions on samples that exclude harvests preceding the calendar year containing a crisis (autumn 1883, 1889 and so on).

We present results from 2SLS using regional weather data as instruments, as well as from OLS. In 2SLS first-stage specifications follow DHR (2009), who give details on the weather data and the instruments' strength. Each crop's harvest is projected on a different set of weather time-series (different geographic regions, different months' precipitation and temperature). Prior information early twentieth-century statistical studies of weather effects on crop yields - guided the choice of weather variables for each crop. Recall DHR's results indicate that cotton harvest fluctuations in 
general, not just those due to weather, were exogenous to macroeconomic conditions. Thus, we do not expect 2SLS to show different patterns from OLS here. We present the 2SLS results for robustness.

Results show the patterns we hypothesized. The deviation from trend in the cotton harvest had positive effects on American stock prices and NYCH bank deposits within the harvest season, and positive effects on IP about six months later. The cotton harvest had negative effects on American bond yields (which move inversely to bond prices) and commercial paper rates, with the same timing as the stock-price effects. That indicates stock prices were reflecting a general effect of the cotton harvest on required returns to American assets subject to international arbitrage. British stock prices and British bond yields do not show these effects. American call-money rates respond weakly, if at all, to the cotton harvest. Cotton's effects on American financial markets and IP appeared prior to the onset of financial crises and whether or not a crisis occurred. Deviations from trend in wheat and corn harvests do not have any of these effects on financial and macroeconomic variables.

Our hypotheses do not have clear implications about exactly when in the year cotton harvest fluctuations should have begun to affect financial variables. In principle, cotton harvest fluctuations could be correlated with changes in asset prices prior to the harvest season. Sophisticated investors could have traded on forecasts of the coming harvest, which were available beginning in June. On the other hand, it is clear that contemporaries viewed harvest forecasts as unreliable until the onset of the harvest season in August. ${ }^{24}$ Certainly, contemporaries had neither the techniques nor all of the weather data we use ourselves to forecast harvests as IV's. We look for "effects" of harvest fluctuations on financial variables prior to the third quarter of the harvest year, but find no significant relations.

\section{1) Statistical specifications}

\footnotetext{
${ }^{24}$ Moore (1917, p. 6); New York Times (May 24, 1907, p. 13; June 19, 1904, p. FS1); Manchester Guardian (Nov. 25, 1902 p. 11; June 6, 1904 p. 10; June 17, 1907 p. 11). Through November forecasts diverged widely and were substantially revised. In a pioneering statistical study Moore (1917) developed methods to forecast cotton harvests with weather data, and tested the forecast value of information in the Agriculture Department's monthly crop reports. He concluded that the report available in June "is so erroneous that any forecast from it is spurious. Any money that changes hands as a result of the report is the gain or loss of a simple gamble," while reports available in August "have real value" (p. 166).
} 
Crop production trends were defined to be quadratic in time over 1869-1913 to match DHR (2009). (HP trends or quadratic trends over 1878-1913 gave similar results.) We want to pin down the seasonal timing of harvests' effects but the timing of harvests themselves varied from year to year. The cotton harvest, for example, could peak in September one year, October the next. To allow for some slack we average monthly series up to a quarterly frequency.

Our main dependent variables are changes in stock prices, bank deposits and so on from a preharvest value to Q3 or Q4 of the harvest year, and to each of the four quarters of the calendar year following the harvest. The pre-harvest value is a four-quarter average up through Q2 of the harvest year, for variables known to be subject to strong seasonal influences in the pre-1914 era (industrial production, commercial paper, NYCH bank deposits, call money, London bills, New York stock volume [on stock volume seasonals see Owens and Hardy, 1925]). For other variables, the pre-harvest value is the average for harvest-year Q2. Immediate effects of a harvest, within the harvest season, should appear in regressions with changes to harvest-year Q3 or Q4 of the harvest year on the left-hand side. Delayed effects appear in results for quarters of the following year. To look for "effects" of harvests on financial variables prior to the harvest season, we run regressions where the dependent variables are changes to Q2 of the harvest year from harvest-year Q1 or a four-quarter average up through harvest-year Q1.

Our samples begin with the harvest of autumn 1879, the first after the U.S. resumed gold payments, and stop at the end of 1913. For most variables all-harvest samples have 35 observations for harvest-year Q3 and Q4, 34 observations for following-year Q1-Q4. Samples excluding crisis-year harvests have 30 (29) observations. In the tables, coefficients and standard errors are scaled to the standard deviation of a cotton harvest fluctuation ( 0.12 for harvests $1878-1912)$; standard deviations for wheat $(0.13)$ and corn $(0.14)$ were similar. Thus, the tables give estimated coefficients and SE's multiplied by 0.12 . On a causal interpretation, they give the effect of a one-standard deviation harvest fluctuation. 


\section{2) Results}

Table 2 shows results from the sample including all harvests, and from the sample excluding harvests that took place within a calendar year containing a crisis. For OLS, all three crops' harvest fluctuations were included together. For 2SLS, we ran separate regressions for each crop. The harvest year is year 1; the following year is year 2 .

For panels a and b, dependent variables are changes in logs of NYCH bank deposits and the stock price index. For panel c dependent variables are changes in NYSE trading volume (number of shares), another indicator of stock prices: in modern data, trading volume has a strong positive correlation with changes in stock prices (Karpoff, 1987). For all of these financial variables, cotton coefficients are generally positive, and significantly different from zero at conventional levels, starting in harvest-year Q3 or Q4. Financial crises occurred in Q2 or later. Thus, cotton's effects appeared prior to the occurrence of any financial crisis. Wheat and corn coefficients do not show these patterns. For stock prices they are positive and significant only in some cases. For deposits, wheat and corn coefficients are actually negative in many cases.

Panel d shows results for industrial production. Samples are smaller here because the monthly IP index begins with January 1884. To define a pre-harvest value for the 1884 harvest season, we extrapolated from the change in Davis' (2004) annual IP index as for Figure 3. (Coefficients from IP regressions were not substantially different if we began samples with the 1885 harvest.) Samples excluding crisis-year harvests are too small for reliable inference, so we present results from OLS regressions with the cotton harvest alone on the RHS to save degrees of freedom. For Q3 and Q4 of the harvest year, cotton coefficients are not significantly different from zero; some are negative in sign. Cotton coefficients are positive and significantly different from zero for Q1 or Q2 of the following year, and are largest for following-year Q3. (None of the wheat or corn coefficients is positive and significantly different from zero.) Thus, cotton's effect on industrial production did not appear before the end of the harvest year, and was strongest about a year after the harvest. 
Table 3 gives results from samples excluding harvests preceding calendar years containing crises. Coefficients in panels a through d show the same patterns as in Table 2. Thus, cotton harvests affected New York deposits, stock prices and real activity whether or not they were followed by a crisis.

We hypothesized that cotton harvests could affect stock prices prior to industrial production through an effect on required returns on assets subject to international arbitrage. Cotton's positive effects on stock prices should thus be matched by negative effects on bond yields. The best indicator of American bond yields for the pre-1914 era is Macaulay's (1938) index of American railroad bonds' yields to maturity. Panels e of Tables 2 and 3 show results with changes in this bond yield index as dependent variables. Cotton coefficients are indeed negative and statistically significant by harvestseason Q4.

Cotton harvests should also affect interest rates at the maturity of time money or commercial paper. There is no continuous series on time money rates for 1879-1913 but we can examine commercial paper rates. These results are in panel f of Tables 2 and 3 . Cotton coefficients are indeed negative and significantly different from zero in harvest-year Q3 and/or Q4. Wheat coefficients are significantly positive in OLS results from the sample excluding crisis-year harvests. That is consistent with our argument that wheat harvests had relatively strong effects on money demand, and matches negative coefficients on wheat for NYCH deposits in panel a. The previous section's argument also implied that cotton's interest-rate effect could diminish in the post-harvest period, absent further shocks. In Table 3's results from the sample excluding pre-crisis harvests, cotton coefficients are positive and significant in the harvest season, small and not significantly different from zero in the following year.

The magnitude of cotton coefficients for commercial paper, in quarters where they are significantly different from zero, is about ten times the corresponding coefficients for bond yields in e). That makes sense. As the maturity of the bonds in the yield index is at least ten years, the change in 
their yields could be about one-tenth of the change in short-term rates if market participants expected the latter to persist about a year, even if there were no changes in total premiums for bonds' term, relative liquidity and default risk.

The coefficient values in Tables 2 and 3 imply that stock prices fell about 1.75 percent for each 25 basis point increase in the commercial paper rate. We know of no evidence that would allow us to judge whether this is reasonable for the pre-1914 era, but it is roughly in line with patterns in modern American data. Rigobon and Sack (2004) estimate that "an unanticipated 25-basis point increase" in the Fed's interest-rate target, which is directly reflected in bill-maturity rates, "results in a $1.7 \%$ decline in the S\&P index" (p. 1567). Bernanke and Kuttner (2005) find that an "unanticipated 25-basis-point cut in the Federal funds rate target" in a period when changes in the target affected bill rates about oneto-one, and could be expected to persist for about a year (their figure 6), was "associated with about a $1 \%$ increase in broad stock indexes" (p. 1221).

Results for call money rates are in Table 2 panel g. Recall our essential argument - cotton harvests affected financial conditions through international asset markets - has ambiguous implications here: call money rates were not directly subject to international arbitrage, and there is reason to believe they would be positively affected by increases in securities prices. In fact, some of the cotton coefficients in this panel are negative and significant, but most are not.

Results for British stock (equity) prices, consol yields and bill rates are in Table $2 \mathrm{~h}$ - j. Our argument implies that cotton harvests should not affect these variables in the same way they affect American stock prices and interest rates. For bill rates and consol yields, no coefficient is significantly different from zero at the five percent level. For the stock price index, in OLS on the full sample the coefficient on cotton in harvest-season Q3 is significantly different from zero at the five percent level, but its sign is negative.

Key to our argument is that wheat harvest fluctuations did affect international gold flow and high-powered money supply, as shown by DHR (2009) in annual data, even though wheat harvests did 
not affect financial variables as cotton did. Table $2 \mathrm{k}$ ) shows results of regressions where the dependent variable is cumulative net gold inflow through the end of the quarter, as a fraction of the pre-harvest high-powered money supply. Coefficients on wheat as well as cotton are positive and many are significantly different from zero at five percent or better.

Finally, Table 4 shows results for changes to Q2 of the harvest year, in the variables that show effects of cotton harvests within the harvest season: NYCH bank deposits, New York stock prices and trading volume, New York bond yields and commercial paper rates. None of the coefficients is significantly different from zero.

\section{5) Cotton harvests and key variables in crisis years}

Our regression results imply poor cotton harvests generally tended to lower stock prices; drain deposits from New York banks; and depress real activity. Earlier, we showed that the crises of 1884, 1893 and 1896 were all preceded by extremely poor cotton harvests, stock-price declines and downturns of real activity from cyclical peaks; 1893 and 1896 were also preceded by persistent declines in NYCH deposits. Returning to Table 1, note that the more reliable business cycle chronologies place the peaks preceding 1884, 1893 and 1896 around the beginning of the crisis year. The NBER date for the pre-1884 peak is much earlier, but recall Romer (1994) finds that many NBER peaks are dated too early. Annual industrial production peaked in 1883, so real activity must actually have peaked in late 1883 or 1884 . This timing is consistent with the effect of a poor cotton harvest in the prior autumn: as the regressions with industrial production on the left-hand side give positive and significant coefficients for following-year Q1, they indicate that cotton harvests started to affect real activity around the beginning of the following year.

As further evidence that poor cotton harvests triggered these crises, we present scatterplots of cotton harvest deviations from trend (the same variable used in the regressions) against changes in stock prices, NYCH deposits and industrial production. For stock prices in Figure 6 and NYCH deposits in Figure 7, the vertical axis is the change from the pre-harvest period to Q1 of the calendar year following the harvest. (Recall that all crises occurred in Q2 or later.) For industrial production in 
Figure 7, the vertical axis is the change in the log of Davis' annual index from the harvest year to the following calendar year, so that we can include 1880-1883. Triangles mark the harvests that preceded crisis years.

The scatterplots show that our regression results are not relics of a few extreme observations. More importantly, they show that the declines in industrial production and stock prices in 1884, 1893 and 1896, and the deposit declines in early 1893 and 1896, can indeed be explained by the prior years' cotton harvests. The observations for the 1883, 1892 and 1895 harvests are not outliers. They are in line with the rest of the scatter, including or excluding the crisis-year observations.

Finally, recall we argued the crises of November 1890 and October 1907 were due to foreign financial disturbances, not poor cotton harvests. Our regression results imply that a large cotton harvest would tend to counter the effects of a foreign financial disturbance, as it boosted stock prices, deposits in New York banks and real activity. The cotton harvest of autumn 1890, coincident with the American echo of the London Baring's crisis, was extraordinarily large and generated large export revenues. This can explain why the 1890 crisis, unlike the others, was not associated with an apparent decline in real activity or spike in bank failures.

The observations corresponding to the harvests of 1890 and 1907 are labeled in Figures 6-8. Consistent with our argument, in figure 6 both of these harvests are obvious outliers: that is, the decline in stock prices across these harvest seasons cannot be accounted for by the cotton harvest. In Figure 8, also, the 1907 harvest is an outlier: the slightly below-trend harvest cannot account for the great decrease in industrial production from 1907 to 1908. The 1890 harvest observation is low relative to the scatter: most cotton harvests as large as 1890's were followed by large increases in industrial production. We cannot be precise about the possible interaction between the financial effects of the bumper cotton harvest versus the London financial crisis. Quantifying the possible effects of the latter is far beyond the scope of this paper. But based on the figure it is plausible that industrial production would have suffered an absolute decline in 1891, if not for the large cotton harvest of autumn 1890.

\section{6) Conclusion}


Five national financial crises, as conventionally defined, took place during the 1879-1913 goldstandard era: in 1884, 1890, 1893, 1896 and 1907. All except 1890 were associated with cyclical downturns and waves of bank failures. Two, in 1890 and 1907, have already been accounted for as the results of sudden stops of European investment in the U.S. We have presented evidence that cotton harvest fluctuations were the exogenous triggers of the other three, in 1884, 1893 and 1896, and may account for the anomalous stability of the American economy around 1890.

Cotton harvests affected New York bank deposits, stock prices and real activity in such a way that a good cotton harvest tended to counteract a foreign financial disturbance, and a poor cotton harvest tended to create crisis conditions in the next year. The channel to financial conditions ran through the effect of export-revenue shocks on required returns to American assets in international capital markets under the gold standard. The cotton crop and cotton export revenues were extremely large coincident with the crisis of November 1890 and extremely poor in the harvest seasons preceding 1884, 1893 and 1896. But cotton harvests affected financial conditions and real activity whether or not a crisis followed.

For American monetary history, we have shown that contemporaries were right to argue that many crises could have been counteracted by an American central bank managing an "elastic" currency. The absence of financial effects from wheat harvests proves the point. Wheat harvest fluctuations affected international gold flows but did not disturb American financial markets because wheat harvest fluctuations had countervailing effects on high-powered money demand. For research on financial crises, we have shown that the factors triggering pre-1914 American crises had many repercussions, including cyclical downturns, which may be hard to distinguish from effects of crises.

\section{Appendix 1: Data sources}

"NBER" refers to the National Bureau of Economic Research Macro History database (http://www.nber.org/databases/macrohistory/)

Bank failures. Failed banks' assets from U.S. Comptroller of the Currency (1921 Table 39; 1932, pp. 5, 8.) The 
annual series given in Comptroller's reports for national banks is for periods ending with October, which does not match the series for other banks. But the detailed records in the reports also give details on closing of each national bank, including the exact date that a receiver was appointed. From these data we calculated assets of failed national banks for the twelve months ending June to match the other banks.

International gold inflow to U.S. Monthly net gold export NBER 14112 (sign reversed).

Commercial paper rate. NBER 13002.

Railroad bond yield index. NBER 13019A.

Stock price index. NBER 11025.

Number of shares traded on New York Stock Exchange. NBER 11002.

Call money rate: Neal and Weidenmier (2003) collected each Thursday's call-money rate from the New York Commercial and Financial Chronicle, beginning with November 27, 1880. When the rate was given as a range (which was most weeks), this is the low end of the range. Weidenmier kindly provided these data (at the time of this writing, available on his website ebutts05.tripod.com/nealweidenmiergsd). For January 1866 through December 1880, the Review of Economics and Statistics (July 1902, Vol. 2 supplement 2, pp. 40-41) gives the monthly average of the weekly low rates of the Financial Review published by the Commercial and Financial Chronicl e. We constructed our quarterly call money rate from a monthly series. Up through November 1880 , this is the REStat series. Starting December 1880, it is the monthly average of the Neal and Weidenmier series.

London equity price index. NBER 11012.

London consol yield. NBER series 13041 (2) linked to 13041 (3) at April 1884.

London bill rate: NBER 13016.

New York City Clearinghouse member bank deposits, monthly averages. January 1879-December 1913 from Persons (1919), pp. 176-177, 180-181. Monthly data for 1878 calculated from weekly data in Andrew (1910).

Cotton, wheat and corn production: Carter et. al. (2006), Da696, Da718, Da756.

Cotton and wheat export revenues. United States Department of Agriculture, Bureau of Statistics, Exports of Farm Products from the United States, 1851-1908, Bulletin 75 (U.S. GPO, 1910) and Yearbook (1913, 1916).

Wholesale price index: Warren and Pearson (1932).

\section{Appendix 2: New York City banks' unsecured loans to speculators}

1884 The crisis of 1884 occurred after stock prices had been falling for months. Sprague (1910, p. 110) observed this "brought about the downfall of a number of speculators whose plans might have proved successful if general conditions had been such as to lead to a rise in security values." The crisis hit in May with runs on the Marine National, Second National and Metropolitan banks. 
The Marine National had been lending without collateral to a brokerage, Grant and Ward, by allowing it to overdraw certified checks. The bank's president was a partner in the brokerage, and the brokerage's controlling partner was a director of the bank. When the brokerage failed the bank was left holding the bag, unable to cover its NYCH clearing debit. ${ }^{25}$

The Second National suffered a run when it was revealed that its president had been borrowing bank funds to finance stock purchases, faking paperwork to make it appear the funds had been lent to others on proper collateral. The general decline in stock prices brought him down and left the bank potentially insolvent. $^{26}$

The Metropolitan's president was rumored to be "a very large speculator...the public having become suspicious, and apparently believing that he was a large borrower from the bank, and had loaned money to parties who were interested with himself, all of whom were assumed to have lost largely by [the decline in stock prices], rumors were circulated which excited distrust and suspicion against his bank and caused the run" (U.S. Comptroller of the Currency 1884, p. XLII). The NYCH authorized loan certificates to save the Metropolitan, which was actually solvent, "especially because of its extensive relationships with interior banks...its closing could easily spread fear and uncertainty throughout the country" (Wicker, 2000, p. 37).

The Newark Savings Institution was under a court order that forbade it to lend to brokerage houses, even on collateral, but it lent to the Fisk and Hatch brokerage, which went under. The loans were supposed to be secured by government bonds kept in a special box in the Fisk and Hatch office; the box was empty (New York Times, Dec. 31, 1884, p. 2).

"Although the crisis was largely confined to New York, the alarm which was felt by interior banks was sufficient to bring about a withdrawal of their deposits in New York" (Myers, 1931, p. 412). 1890 In autumn 1890, following months of decline in stock prices "It was evident that further

\footnotetext{
${ }^{25}$ New York Times, May 7, 1884 p. 1, May 10, 1884, p. 1; Sprague, 1910, pp. 110-111; Ward, 2012, pp. $203-23$.
}

${ }^{26}$ New York Times, May 14, 1884, p. 1; May 18, 1884, p. 1 
decline could hardly fail to bring about extensive failures" (Sprague, 1910, p. 141). Interior banks began to withdraw balances from New York even though their own deposits were stable (Myers, 1931, p. 414). The Bank of North America had been lending to a brokerage, Decker, Howell and Company, without collateral by allowing it to overdraw certified checks. The brokerage failed at least partly due to the general decline in stock prices, leaving the bank unable to cover a net debit at the $\mathrm{NYCH}$ and spurring a run. The NYCH issued loan certificates to save the Bank of North America and another bank which was suffering heavy deposit drains. ${ }^{27}$ The following weeks saw failures of several more New York brokerages and banks (Sprague, 1910, pp. 141-145).

1907 In 1907 stock prices began to fall in January. By late summer "there occurred on the Stock Exchange sales so enormous, and at such sacrifice of values, as to convince the experienced Wall Street man, despite official denials, that forced liquidation by the largest financiers was under way" (Noyes, 1909, p. 260). In October a decline in a copper mining company's stock price broke a group of speculators who had attempted to "corner" it (Moen and Tallman, 1990). After two brokerages associated with the group went under, runs ensued on several banks and two trust companies (the Knickerbocker Trust and the Trust Company of America) rumored to be connected to the group. The speculators had, in fact, controlled several New York City banks and helped themselves to unsecured loans. ${ }^{28}$ Meanwhile, "the banks out of town began to draw down their deposits in New York" (Myers, 1931, p. 417). After runs on more trust companies and banks, the NYCH authorized loan certificates and payments restrictions. J.P. Morgan engineered a rescue of a large brokerage, reportedly stating that if the firm were allowed to fail "there is no telling...how many other houses will drop with it, and how many banks might be included in the consequences" (Wicker, 2000, pp. 94-96).

\section{Bibliography}

Alogoskoufis, George S. and Ron Smith. "The Phillips Curve, the Persistence of Inflation, and the

${ }^{27}$ Wicker, 2000, p. 45; New York Times, Nov. 12, 1890; London Banker's Magazine, Dec. 1890, p. 1965. 
Lucas Critique: Evidence from Exchange-rate Regimes.” American Economic Review. 81:5, (Dec. 1991): 1254-75.

Andrew, A. Piatt. "The Influence of the Crops upon Business in America." Quarterly Journal of Economics. 20:3, (May 1906): 323-52.

-- Statistics for the United States, 1867-1909. (National Monetary Commission) Washington, DC: GPO, 1910.

Barsky, Robert B. "The Fisher Effect and the Forecastability and Persistence of Inflation." Journal of Monetary Economics, 1987. 19, 3-24.

-- and J. Bradford DeLong. "Forecasting Pre-World War I Inflation: the Fisher Effect and the Gold standard." Quarterly Journal of Economics, August 1991, 106 (3), 815-836.

Bernanke, Ben S. "Nonmonetary Effects of the Financial Crisis in the Propagation of the Great Depression." American Economic Review. 73:3, (June 1983): 257-276.

-- and Kenneth N. Kuttner. "What Explains the Stock Market's Reaction to Federal Reserve Policy?" Journal of Finance. 60:3, (June 2005): 1221-1257.

Bordo, Michael. "The Impact and International Transmission of Financial Crises: Some Historical Evidence, 1870-1933." Revista di Storia Economica. 2, 1985, 41-78.

-- and William G. DeWald. "Bond Market Inflation Expectations in Industrial Countries: Historical Comparisons." NBER Working Paper 8582, November 2001.

-- and Joseph G. Haubrich. "Credit Crises, Money and Contractions: An Historical View." Journal of Monetary Economics.57, (2010): 1-18.

-- "Sudden Stops, Financial Crises and Original Sin in Emerging Countries: Deja Vu?" NBER Working Paper 12393, July 2006.

-- and Ronald McDonald, "Interest Rate Interactions in the Classical Gold Standard, 1880-1914: Was There Any Monetary Independence?” Journal of Monetary Economics. 52:2, (March 2005): 307-27.

Bruner, Robert F. and Sean D. Carr, The Panic of 1907: Lessons Learned from the Market's Perfect Storm. New York, Wiley, 2007.

Calomiris, Charles and Gary Gorton. "The Origins of Banking Panics: Models, Facts, and Bank regulation.” In Financial Markets and Financial Crises, edited by R. Glenn Hubbard Chicago: University of Chicago for NBER, 1991.

Calomiris, Charles and Glenn Hubbard. "International Adjustment under the Classical Gold Standard: Evidence for the United States and Britain, 1879-1914." In Modern Perspectives on the Gold Standard, edited by Tamim Bayoumi, Barry Eichengreen and Mark P. Taylor. New York: Cambridge University Press, 1996.

Calvo, Sara and Carmen M. Reinhart. "Capital Flows to Latin America: Is There Evidence of Contagion Effects?" In Private Capital Flows to Emerging Markets, edited by Guillermo Calvo and Morris Goldstein Washington, DC: Institute for International Economics, 1996.

Canjels, Eugene, Gauri Prakash-Canjels and Alan M. Taylor, "Measuring Market Integration: Foreign Exchange Arbitrage and the Gold Standard, 1879-1913," Review of Economics and Statistics. $86: 4$, (Nov. 2004) 868-882.

${ }^{28}$ Moen and Tallman, 1990; Wicker, 2000, p. 89; Conant, 1909, p. 713; New York Times, Oct. 23, 1907, p. 1; Oct. 24, 1907, p. 2. 
Carter, Susan, Scott S. Gartner, Michael R. Haines, Alan L. Olmstead, Richard Sutch, and Gavin Wright, eds., Historical Statistics of the United States: Earliest Times to the Present. Millennial Edition. New York: Cambridge University Press, 2006.

Caudill, Steven B. "Dichotomous Choice Models and Dummy Variables." The Statistician, 1987, 36 (4), 381-83.

Chari, V. V. “'Banking without Deposit Insurance or Bank Panics: Lessons from a Model of the U.S. National Banking System.” Federal Reserve Bank of Minneapolis Quarterly Review. Summer 1989, 3-19.

Christiano, Lawrence J., Martin Eichenbaum and Charles L. Evans, "Nominal Rigidities and the Dynamic Effects of a Shock to Monetary Policy.” Journal of Political Economy. 113:1, (Feb. 2005):1-45.

Conant, Charles A. A History of Modern Banks of Issue. New York: G.P. Putnam, 1909.

Covert, James R. Seedtime and Harvest: Cereals, Flax, Cotton, and Tobacco: Dates of Planting and Harvesting East of Meridians 102-104, in the United States. Washington, DC: USDA, 1919.

Davis, Joseph H. “An Annual Index of U.S. Industrial Production, 1790-1915.” Quarterly Journal of Economics. 119:4, (Nov. 2004): 1177-1215.

-- "An Improved Annual Chronology of U.S. Business Cycles since the 1790s." Journal of Economic History. 66:1, (March 2006): 103-121.

Davis, Joseph H., Christopher Hanes and Paul W. Rhode. "Harvests and Business Cycles in Nineteenth-Century America." Quarterly Journal of Economics. 124: 4, (Nov. 2009a): 16751727. Working paper version: NBER Working Paper 14686 (2009b).

DeLong, J. Bradford and Lawrence Summers. "The Changing Cyclical Variability of Economic Activity in the United States." In The American Business Cycle: Continuity and Change, edited by Robert J. Gordon. Chicago: University of Chicago Press for NBER, 1986, 679-719.

Diamond, Douglas W. and Phillip H. Dybvig. "Bank Runs, Deposit Insurance and Liquidity.” Journal of Political Economy. 91:3, (June 1983): 401-419.

Edelstein, Michael. Overseas Investment in the Age of High Imperialism: The United Kingdom, 18501914. New York: Columbia University Press, 1982.

Eichengreen, Barry. Golden Fetters. Oxford, U.K.: Oxford University Press, 1992.

Fels, Rendigs, American Business Cycles 1865-1897. Chapel Hill: University of North Carolina Press, 1959.

Friedman, Milton, and Anna Jacobson Schwartz, A Monetary History of the United States, 1867-1960. Princeton: Princeton University Press, 1963.

-- Monetary Trends in the United States and the United Kingdom. University of Chicago for NBER: Chicago, 1982.

Goodhart, Charles A. E. The New York Money Market and the Finance of Trade, 1900-1913. Cambridge: Harvard Univ. Press, 1969.

Gorton, Gary. "Banking Panics and Business Cycles." Oxford Economic Papers. 40:4, (Dec. 1988): 751-781.

-- Slapped by the Invisible Hand: The Panic of 2007. Oxford, U.K.: Oxford University Press, 2010. Hanes, Christopher. "Degrees of Processing and Changes in the Cyclical Behavior of Prices in the United States, 1869-1990.” Journal of Money, Credit and Banking. 31:1, (Feb. 1999): 35-53. 
-- and John James. "Wage Rigidity in the Great Depression." Working Paper, March 2010.

-- and Paul W. Rhode. "Harvests and Financial Crises in Gold-Standard America." Working Paper, Oct. 2012.

Hawtrey, R. G. A Century of Bank Rate. London: Longmans, Green, 1938.

Homer, Sidney and Richard Sylla. A History of Interest Rates. 4th edition. Hoboken, NJ: Wiley, 2005. Indianapolis Monetary Commission. Report of the Monetary Commission of the Indianapolis Convention. Chicago: University of Chicago Press, 1898.

Jalil, Andrew. "A New History of Banking Panics in the United States, 1825-1929: Construction and Implications." Working Paper, November 2009.

James, John A. Money and Capital Markets in Postbellum America. Princeton: Princeton University Press, 1978.

James, John A., James McAndrews and David F. Weiman. "Wall Street and Main Street: the Macroeconomic Consequences of Bank Suspensions in New York on the National Payments System, 1866 to 1914.” Working Paper, 2011.

Kaminsky, Graciela L., Carmen M. Reinhart and Carlos A. Vegh, "The Unholy Trinity of Financial Contagion," Journal of Economic Perspectives. 17:4 (Autumn 2003): 51-74.Karpoff, Jonathan M. "The Relation between Price Changes and Trading Volume: A Survey." Journal of Financial and Quantitative Analysis. 22:1, (March 1987): 109-126.

Kemmerer, E. W. Seasonal Variations in the Relative Demand for Money and Capital in the United States. National Monetary Commission, U.S. Senate Doc. 588. Washington, DC: GPO, 1910. Kindleberger, Charles A. Manias, Panics and Crashes. 3rd edition. New York: John Wiley, 1996. Kouri, Pentti J.K. and Michael G. Porter, "International Capital Flows and Portfolio Equilibrium," Journal of Political Economy. 82:3 (May 1974): 443-467.

Lauck, W. Jett. The Causes of the Panic of 1893. Boston: Houghton Mifflin, 1907.

MacAulay, Frederick R. Some Theoretical Problems Suggested by the Movements of Interest Rates, Bond Yields and Stock Prices in the United States Since 1856. New York: NBER, 1938.

Margraff, Anthony W. International Exchange. Fourth edition. Chicago: Marshall-Jackson, 1912. Miron, Jeffrey A. "Financial Panics, the Seasonality of the Nominal Interest Rate, and the Founding of the Fed." American Economic Review. 76:1, (March 1986): 25-140.

Miron, Jeffrey A. and Christina D. Romer. "A New Monthly Index of Industrial Production, 1884 1940.” Journal of Economic History. 50:2, (June 1990): 321-337.

Mishkin, Frederic S. "Asymmetric Information and Financial Crises: A Historical Perspective.” In Financial Markets and Financial Crises, edited by R. Glenn Hubbard. Chicago: University of Chicago for NBER, 1991.

Moen, Jon and Ellis Tallman. "Lessons from the Panic of 1907." Federal Reserve Bank of Atlanta Economic Review, May/June 1990, 2-13.

Moore, Henry L. Forecasting the Yield and Price of Cotton. New York: MacMillan, 1917.

Morgensten. Oskar. International Financial Transactions and Business Cycles. Princeton, NJ: Princeton University Press for NBER, 1959.

Morris, Stephen and Hyun Song Shin. "Rethinking Multiple Equilibria in Macroeconomic Modeling." NBER Macroeconomics Annual. 15, 2000: 139-161.

Myers, Margaret G., The New York Money Market, Volume I: Origins and Development. New York: 
Columbia University Press, 1931.

Neal, Larry, and Marc Weidenmier, "Crises in the Global Economy from Tulips to Today," In Globalization in Historical Perspective, edited by Michael D. Bordo, Alan M. Taylor and Jeffrey Williamson. Chicago: University of Chicago Press, 2003.

Noyes, Alexander Dana. Thirty Years of American Finance. New York: G.P. Putnam, 1909.

Odell, Kerry A. and Marc D. Weidenmier. "Real Shock, Monetary Aftershock: the 1906 San Francisco Earthquake and the Panic of 1907." Journal of Economic History. 64:4, (Dec. 2004): 1002-27.

Owens, Richard N. and Charles O. Hardy. Interest Rates and Stock Speculation. New York: MacMillan, 1925.

Persons, Warren M. "Application of the Method to the Data, (A) The Individual Series." Review of Economics and Statistics. I:2, (April 1919):139-181.

Reinhart, Carmen and Kenneth S. Rogoff. This Time is Different: Eight Centuries of Financial Folly. Princeton: Princeton University Press, 2009.

-- "From Financial Crisis to Debt Crisis." American Economic Review, 101:5, (Aug. 2011): 1676-1706. Rigobon, Roberto and Brian Sack. "The Impact of Monetary Policy on Asset Prices." Journal of Monetary Economics, 51, (2004): 1553-1575.

Romer, Christina D. "Remeasuring Business Cycles." Journal of Economic History. 54:3, (Sept. 1994): 573-609.

Sayers, R. S. The Bank of England, 1891-1944. Cambridge, U.K.: Cambridge University Press, 1976.

Schularick, Moritz and Alan M. Taylor. "Credit Booms Gone Bust: Monetary Policy, Leverage Cycles and Financial Crises, 1870-2008." American Economic Review, April 2012, 102(2), 1029-1061.

Smith, K.C. and G.F. Horne, “An Index Number of Securities, 1867-1914.” Royal Economic Society and London and Cambridge Economic Service, Memorandum No. 47, 1934.

Sprague, O. M. W. “The New York Money Market.” Economic Journal. 13: 49, (March 1903): 30-57. -- "Proposals for Strengthening the National Banking System." Quarterly Journal of Economics. 24:2, (Feb. 1910): 201-242.

-- History of Crises under the National Banking System. Washington, DC: GPO, 1910.

Timberlake, Richard. The Origins of Central Banking in the United States. Cambridge: Harvard University Press, 1978.

United States Bureau of the Census. Cotton Production, 1909. Bulletin 107. Washington, DC: GPO, 1910.

United States Comptroller of the Currency. Annual Report for 1884. Washington, DC: GPO, 1884.

-- Annual Report for 1920, Vol. 2. Washington, DC: GPO 1921.

-- Annual Report for 1931. Washington, DC: GPO 1932.

United States Department of Agriculture. 1883 Annual Report. Washington, DC: GPO, 1883.

-- 1892 Annual Report. Washington, DC: GPO 1892.

-- Monthly Crop Reporter.

--Bureau of Statistics. Monthly Report of Statistician.

Ward, Geoffrey C. A Disposition to be Rich: How a Small-Town Pastor's Son Ruined an American President, Brought on a Wall Street Crash, and Made Himself the Best-Hated Man in the United States. New York: Knopf, 2012.

White, Horace. "The Stock Exchange and the Money market." Annals of the American Academy of Political and Social Science, November 1910, 36 (3), 85-95. 
Wicker, Elmus. Banking Panics of the Gilded Age. Cambridge, U.K.: Cambridge University Press, 2000.

-- The Great Debate on Banking Reform: Nelson Aldrich and the Origins of the Fed. Columbus, Ohio: Ohio State University Press, 2005.

Wilkins, Mira. The History of Foreign Investment in the United States to 1914. Cambridge: Harvard University Press, 1989.

Wilson, Jack W., Richard E. Sylla and Charles P. Jones. "Financial Market Panics and Volatility in the Long Run, 1830-1988.” In Crashes and Panics: The Lessons from History, edited by Eugene White. Homewood, IL: Dow Jones-Irwin, 1990.

Woodford, Michael. "Financial Intermediation and Macroeconomic Analysis." Journal of Economic Perspectives, 24:4 (Fall 2010): 21-44.

Woodlock, Thomas F. "The Stock Exchange and the Money Market." In The Currency Problem and the Present Financial Situation, New York: Columbia University Press, 1908. 


\section{Tables}

Table 1 Dates, crises and business-cycle turning points
Wicker, $\underline{\text { Crises }}$
1884 May 1884 May 1884 May 1
1890 Nov. 1890 Nov. 1890 Nov. ${ }^{1}$
1893 May 1893 June 1893 June$^{1}$, Aug. ${ }^{2}$
1896 Oct. 1896 October. $^{3}$
1907 Oct. 1907 Oct. 1907 Oct. 1,2
${ }^{1}$ Issuance of clearinghouse certificates
${ }^{2}$ Suspension of cash payments
3 Authorization of clearinghouse certificates
First column gives Wicker's (2000, p. 9) months of "panic onset," which are the same as Kemmerer's [1910, p. 222] months "panic began" or "crisis began." Second column is Calomiris and Gorton's "height of panic" (1991, Table 4.1). NYCH actions from Wicker (2000), Calomiris and Gorton (1991, p. 114). Business cycle dates from NBER website, Romer (1994), Davis (2006)
Business cycles
Preceding business cycle peak (following trough)

$\begin{array}{lll}\text { NBER } & \underline{\text { Romer }} & \underline{\text { Davis }} \\ \text { 1882 Mar.(1885 May) } & \text { NA } & 1883 \text { (1885) } \\ \text { 1890 July(1891 May) } & \text { 1887 Feb.(1887 Jul.) } & \\ \text { 1893 Jan.(1894 June) } & \text { 1893 Jan.(1894 Feb.) } & 1892(1894) \\ \text { 1895 Dec.(1897 June) } & \text { 1896 Jan.(1897 Jan.) } & 1895(1896) \\ \text { 1907 May(1908 June) } & \text { 1907 July(1908 June) } & 1907(1908)\end{array}$


Table 2 Effects of Harvest Fluctuations in Harvest Season and Following Year 1879-1913

Coefficient scaled to one SD log harvest fluctuation $=\mathbf{0 . 1 2}$

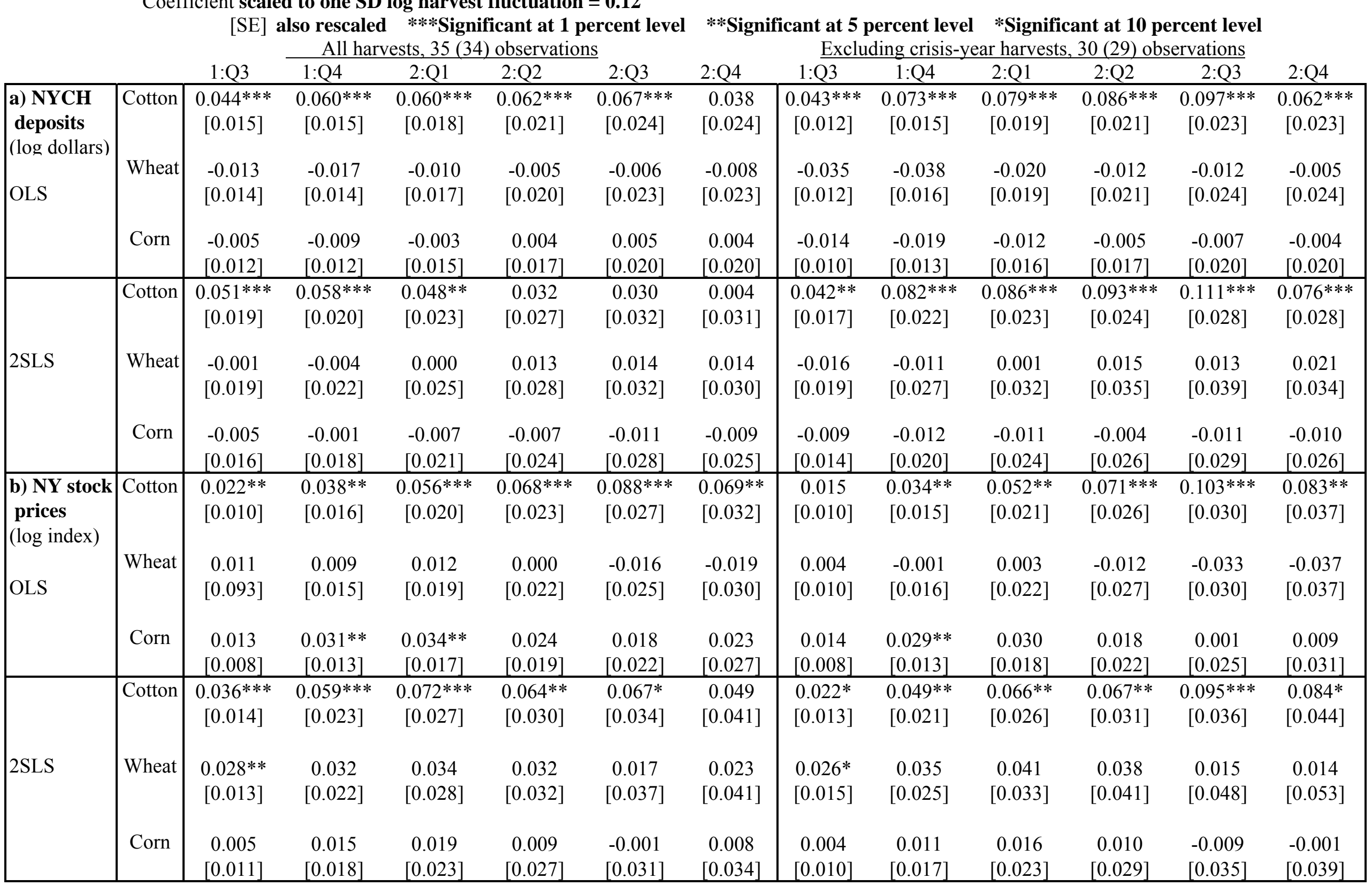




\begin{tabular}{|c|c|c|c|c|c|c|c|c|c|c|c|c|c|}
\hline & \multicolumn{7}{|c|}{ All harvests, 35 (34) observations } & \multicolumn{5}{|c|}{ Excluding crisis-year harvests, 30 (29) observations } \\
\hline & & 1:Q3 & 1:Q4 & 2:Q1 & $2: \mathrm{Q} 2$ & 2:Q3 & 2:Q4 & 1:Q3 & $1: \mathrm{Q} 4$ & 2:Q1 & 2:Q2 & 2:Q3 & $2: \mathrm{Q} 4$ \\
\hline \multirow{3}{*}{$\begin{array}{l}\text { c) NY stock } \\
\text { volume } \\
\text { (log shares) } \\
\text { OLS }\end{array}$} & Cotton & $\begin{array}{c}0.110^{* *} \\
{[0.052]}\end{array}$ & $\begin{array}{c}0.166^{* * *} \\
{[0.050]}\end{array}$ & $\begin{array}{c}0.176^{* *} \\
{[0.070]}\end{array}$ & $\begin{array}{c}0.236^{* * * *} \\
{[0.067]}\end{array}$ & $\begin{array}{c}0.148 * * \\
{[0.061]}\end{array}$ & $\begin{array}{c}0.167 * * \\
{[0.070]}\end{array}$ & $\begin{array}{c}0.119 * * \\
{[0.058]}\end{array}$ & $\begin{array}{c}0.140 * * * \\
{[0.054]}\end{array}$ & $\begin{array}{l}0.168 * * \\
{[0.078]}\end{array}$ & $\begin{array}{c}0.225 * * * \\
{[0.074]}\end{array}$ & $\begin{array}{c}0.163 * * \\
{[0.063]}\end{array}$ & $\begin{array}{l}0.195 * * \\
{[0.077]}\end{array}$ \\
\hline & Wheat & $\begin{array}{c}-0.034 \\
{[0.049]}\end{array}$ & $\begin{array}{c}-0.080 * \\
{[0.047]}\end{array}$ & $\begin{array}{c}0.026 \\
{[0.066]}\end{array}$ & $\begin{array}{c}-0.069 \\
{[0.063]}\end{array}$ & $\begin{array}{c}-0.090 \\
{[0.058]}\end{array}$ & $\begin{array}{c}-0.070 \\
{[0.066]}\end{array}$ & $\begin{array}{l}-0.065 \\
{[0.059]}\end{array}$ & $\begin{array}{c}-0.098 \\
{[0.054]}\end{array}$ & $\begin{array}{c}-0.013 \\
{[0.079]}\end{array}$ & $\begin{array}{l}-0.093 \\
{[0.075]}\end{array}$ & $\begin{array}{c}-0.087 \\
{[0.064]}\end{array}$ & $\begin{array}{c}-0.009 \\
{[0.078]}\end{array}$ \\
\hline & Corn & $\begin{array}{c}0.066 \\
{[0.042]} \\
\end{array}$ & $\begin{array}{c}0.091 \\
{[0.041]} \\
\end{array}$ & $\begin{array}{c}0.095 \\
{[0.058]}\end{array}$ & $\begin{array}{c}0.017 \\
{[0.055]}\end{array}$ & $\begin{array}{c}0.007 \\
{[0.051]}\end{array}$ & $\begin{array}{c}0.060 \\
{[0.058]}\end{array}$ & $\begin{array}{c}0.047 \\
{[0.048]} \\
\end{array}$ & $\begin{array}{c}0.095 \\
{[0.044]} \\
\end{array}$ & $\begin{array}{c}0.083 \\
{[0.065]} \\
\end{array}$ & $\begin{array}{c}-0.002 \\
{[0.062]}\end{array}$ & $\begin{array}{c}-0.039 \\
{[0.052]} \\
\end{array}$ & $\begin{array}{c}0.015 \\
{[0.064]} \\
\end{array}$ \\
\hline \multirow{3}{*}{ 2SLS } & Cotton & $\begin{array}{c}0.207 * * * \\
{[0.073]}\end{array}$ & $\begin{array}{c}0.238 * * * \\
{[0.074]}\end{array}$ & $\begin{array}{l}0.188^{* *} \\
{[0.091]}\end{array}$ & $\begin{array}{c}0.243 * * * \\
{[0.085]}\end{array}$ & $\begin{array}{c}0.166^{* *} \\
{[0.080]}\end{array}$ & $\begin{array}{c}0.149 \\
{[0.090]}\end{array}$ & $\begin{array}{c}0.251 * * * \\
{[0.081]}\end{array}$ & $\begin{array}{l}0.177 * * \\
{[0.076]}\end{array}$ & $\begin{array}{c}0.169 \\
{[0.094]}\end{array}$ & $\begin{array}{c}0.181^{* *} \\
{[0.089]}\end{array}$ & $\begin{array}{c}0.207 * * * \\
{[0.078]}\end{array}$ & $\begin{array}{l}0.194 * * \\
{[0.095]}\end{array}$ \\
\hline & Wheat & $\begin{array}{c}0.042 \\
{[0.068]}\end{array}$ & $\begin{array}{c}0.009 \\
{[0.073]}\end{array}$ & $\begin{array}{c}0.113 \\
{[0.094]}\end{array}$ & $\begin{array}{c}-0.023 \\
{[0.093]}\end{array}$ & $\begin{array}{c}-0.065 \\
{[0.078]}\end{array}$ & $\begin{array}{c}0.060 \\
{[0.093]}\end{array}$ & $\begin{array}{c}0.047 \\
{[0.086]}\end{array}$ & $\begin{array}{c}0.027 \\
{[0.088]}\end{array}$ & $\begin{array}{c}0.133 \\
{[0.118]}\end{array}$ & $\begin{array}{c}0.010 \\
{[0.113]}\end{array}$ & $\begin{array}{c}-0.024 \\
{[0.092]}\end{array}$ & $\begin{array}{c}0.040 \\
{[0.116]}\end{array}$ \\
\hline & Corn & $\begin{array}{c}0.058 \\
{[0.054]}\end{array}$ & $\begin{array}{l}0.096^{* *} \\
{[0.058]}\end{array}$ & $\begin{array}{c}0.096 \\
{[0.077]}\end{array}$ & $\begin{array}{c}0.023 \\
{[0.079]}\end{array}$ & $\begin{array}{c}0.043 \\
{[0.068]} \\
\end{array}$ & $\begin{array}{c}0.090 \\
{[0.076]}\end{array}$ & $\begin{array}{c}0.030 \\
{[0.060]} \\
\end{array}$ & $\begin{array}{c}0.099 * * \\
{[0.058]}\end{array}$ & $\begin{array}{c}0.080 \\
{[0.081]} \\
\end{array}$ & $\begin{array}{c}0.009 \\
{[0.083]}\end{array}$ & $\begin{array}{r}-0.019 \\
{[0.068]} \\
\end{array}$ & $\begin{array}{c}0.031 \\
{[0.084]}\end{array}$ \\
\hline $\begin{array}{l}\text { d) IP } \\
(\log \text { index) }\end{array}$ & Cotton & $\begin{array}{c}-0.001 \\
{[0.018]}\end{array}$ & $\begin{array}{c}0.018 \\
{[0.024]}\end{array}$ & $\begin{array}{c}0.040^{* *} \\
{[0.020]}\end{array}$ & $\begin{array}{c}0.039 * * \\
{[0.018]}\end{array}$ & $\begin{array}{c}0.071 * * * \\
{[0.019]}\end{array}$ & $\begin{array}{c}0.047^{*} \\
{[0.026]}\end{array}$ & $\begin{array}{l}-0.019 \\
{[0.015]}\end{array}$ & $\begin{array}{c}0.005 \\
{[0.022]}\end{array}$ & $\begin{array}{c}0.022 \\
{[0.015]}\end{array}$ & $\begin{array}{c}0.037 * * * \\
{[0.014]}\end{array}$ & $\begin{array}{c}0.067 * * * \\
{[0.021]}\end{array}$ & $\begin{array}{l}0.051 * * \\
{[0.023]}\end{array}$ \\
\hline \multirow[t]{2}{*}{ OLS } & Wheat & $\begin{array}{c}0.016 \\
{[0.017]}\end{array}$ & $\begin{array}{c}0.013 \\
{[0.023]}\end{array}$ & $\begin{array}{c}0.012 \\
{[0.019]}\end{array}$ & $\begin{array}{c}-0.003 \\
{[0.018]}\end{array}$ & $\begin{array}{c}-0.015 \\
{[0.019]}\end{array}$ & $\begin{array}{c}-0.034 \\
{[0.025]}\end{array}$ & $\begin{array}{c}0.007 \\
{[0.016]}\end{array}$ & $\begin{array}{c}-0.018 \\
{[0.024]}\end{array}$ & $\begin{array}{c}-0.005 \\
{[0.017]}\end{array}$ & $\begin{array}{c}-0.022 \\
{[0.015]}\end{array}$ & $\begin{array}{c}-0.029 \\
{[0.023]}\end{array}$ & $\begin{array}{c}-0.073 * * * \\
{[0.025]}\end{array}$ \\
\hline & Corn & $\begin{array}{c}-0.015 \\
{[0.014]}\end{array}$ & $\begin{array}{c}0.004 \\
{[0.020]}\end{array}$ & $\begin{array}{c}-0.001 \\
{[0.016]}\end{array}$ & $\begin{array}{c}0.009 \\
{[0.015]}\end{array}$ & $\begin{array}{c}-0.005 \\
{[0.016]}\end{array}$ & $\begin{array}{c}-0.024 \\
{[0.021]}\end{array}$ & $\begin{array}{c}-0.014 \\
{[0.013]}\end{array}$ & $\begin{array}{c}-0.007 \\
{[0.019]}\end{array}$ & $\begin{array}{c}-0.010 \\
{[0.013]}\end{array}$ & $\begin{array}{l}-0.010 \\
{[0.012]}\end{array}$ & $\begin{array}{c}-0.014 \\
{[0.018]}\end{array}$ & $\begin{array}{c}-0.041^{*} \\
{[0.020]}\end{array}$ \\
\hline $\begin{array}{l}\text { OLS, cotton } \\
\text { only on RHS }\end{array}$ & Cotton & $\begin{array}{c}-0.001 \\
{[0.018]} \\
\end{array}$ & $\begin{array}{c}0.018 \\
{[0.023]} \\
\end{array}$ & $\begin{array}{l}0.040^{* *} \\
{[0.019]} \\
\end{array}$ & $\begin{array}{c}0.039 * * \\
{[0.018]}\end{array}$ & $\begin{array}{c}0.072 * * * \\
{[0.019]}\end{array}$ & $\begin{array}{c}0.048^{*} \\
{[0.026]} \\
\end{array}$ & $\begin{array}{c}-0.019 \\
{[0.015]} \\
\end{array}$ & $\begin{array}{c}0.004 \\
{[0.022]} \\
\end{array}$ & $\begin{array}{c}0.022 \\
{[0.015]} \\
\end{array}$ & $\begin{array}{c}0.037 * * \\
{[0.014]} \\
\end{array}$ & $\begin{array}{c}0.066 * * * \\
{[0.021]}\end{array}$ & $\begin{array}{l}0.047 * \\
{[0.027]} \\
\end{array}$ \\
\hline \multirow{3}{*}{ 2SLS } & Cotton & $\begin{array}{c}0.021 \\
{[0.024]}\end{array}$ & $\begin{array}{l}0.059 * \\
{[0.033]}\end{array}$ & $\begin{array}{c}0.077 * * * \\
{[0.026]}\end{array}$ & $\begin{array}{l}0.050 * * \\
{[0.023]}\end{array}$ & $\begin{array}{c}0.085 * * * \\
{[0.025]}\end{array}$ & $\begin{array}{c}0.055 \\
{[0.034]}\end{array}$ & $\begin{array}{l}-0.013 \\
{[0.019]}\end{array}$ & $\begin{array}{c}0.026 \\
{[0.029]}\end{array}$ & $\begin{array}{c}0.022 \\
{[0.018]}\end{array}$ & $\begin{array}{c}0.026 \\
{[0.018]}\end{array}$ & $\begin{array}{l}0.057 * * \\
{[0.026]}\end{array}$ & $\begin{array}{c}0.049 \\
{[0.034]}\end{array}$ \\
\hline & Wheat & $\begin{array}{c}0.011 \\
{[0.021]}\end{array}$ & $\begin{array}{c}0.015 \\
{[0.029]}\end{array}$ & $\begin{array}{c}-0.003 \\
{[0.026]}\end{array}$ & $\begin{array}{c}-0.082 \\
{[0.024]}\end{array}$ & $\begin{array}{c}-0.055 \\
{[0.030]}\end{array}$ & $\begin{array}{c}-0.058 \\
{[0.034]}\end{array}$ & $\begin{array}{l}-0.005 \\
{[0.022]}\end{array}$ & $\begin{array}{c}-0.019 \\
{[0.031]}\end{array}$ & $\begin{array}{c}-0.005 \\
{[0.023]}\end{array}$ & $\begin{array}{c}-0.020 \\
{[0.023]}\end{array}$ & $\begin{array}{c}-0.060 \\
{[0.037]}\end{array}$ & $\begin{array}{c}-0.099 * * \\
{[0.040]}\end{array}$ \\
\hline & Corn & $\begin{array}{c}-0.014 \\
{[0.016]}\end{array}$ & $\begin{array}{c}0.008 \\
{[0.023]}\end{array}$ & $\begin{array}{c}0.012 \\
{[0.020]}\end{array}$ & $\begin{array}{c}0.032 \\
{[0.019]}\end{array}$ & $\begin{array}{c}0.006 \\
{[0.023]}\end{array}$ & $\begin{array}{c}-0.009 \\
{[0.026]}\end{array}$ & $\begin{array}{l}-0.013 \\
{[0.014]}\end{array}$ & $\begin{array}{c}-0.006 \\
{[0.021]}\end{array}$ & $\begin{array}{c}-0.007 \\
{[0.015]}\end{array}$ & $\begin{array}{c}0.006 \\
{[0.016]}\end{array}$ & $\begin{array}{c}-0.006 \\
{[0.024]}\end{array}$ & $\begin{array}{l}-0.016 \\
{[0.028]}\end{array}$ \\
\hline
\end{tabular}




\begin{tabular}{|c|c|c|c|c|c|c|c|c|c|c|c|c|c|}
\hline & \multicolumn{4}{|c|}{ All harvests, 35 (34) observations } & \multicolumn{8}{|c|}{ Excluding crisis-year harvests, 30 (29) observations } \\
\hline & & $1: \mathrm{Q} 3$ & $1: \mathrm{Q} 4$ & 2:Q1 & $2: \mathrm{Q} 2$ & 2:Q3 & 2:Q4 & $1: \mathrm{Q} 3$ & $1: \mathrm{Q} 4$ & 2:Q1 & $2: \mathrm{Q} 2$ & 2:Q3 & 2:Q4 \\
\hline \multirow{3}{*}{$\begin{array}{l}\text { e) NY bond } \\
\text { yields } \\
\text { (log index) } \\
\text { OLS }\end{array}$} & Cotton & $\begin{array}{l}-0.027^{*} \\
{[0.015]}\end{array}$ & $\begin{array}{c}-0.041 * * \\
{[0.021]}\end{array}$ & $\begin{array}{l}-0.050^{*} \\
{[0.025]}\end{array}$ & $\begin{array}{c}-0.047 \\
{[0.033]}\end{array}$ & $\begin{array}{c}-0.075^{*} \\
{[0.040]}\end{array}$ & $\begin{array}{c}-0.041 \\
{[0.044]}\end{array}$ & $\begin{array}{l}-0.020 \\
{[0.014]}\end{array}$ & $\begin{array}{c}-0.045^{* *} \\
{[0.021]}\end{array}$ & $\begin{array}{c}-0.065 * * \\
{[0.027]}\end{array}$ & $\begin{array}{c}-0.074 * * \\
{[0.035]}\end{array}$ & $\begin{array}{c}-0.116^{* * *} \\
{[0.041]}\end{array}$ & $\begin{array}{l}-0.080^{*} \\
{[0.046]}\end{array}$ \\
\hline & Wheat & $\begin{array}{l}-0.008 \\
{[0.014]}\end{array}$ & $\begin{array}{c}-0.011 \\
{[0.020]}\end{array}$ & $\begin{array}{c}-0.005 \\
{[0.024]}\end{array}$ & $\begin{array}{c}-0.008 \\
{[0.032]}\end{array}$ & $\begin{array}{c}-0.002 \\
{[0.038]}\end{array}$ & $\begin{array}{c}-0.004 \\
{[0.042]}\end{array}$ & $\begin{array}{c}-0.002 \\
{[0.014]}\end{array}$ & $\begin{array}{c}0.002 \\
{[0.020]}\end{array}$ & $\begin{array}{c}0.010 \\
{[0.027]}\end{array}$ & $\begin{array}{c}0.017 \\
{[0.035]}\end{array}$ & $\begin{array}{c}0.034 \\
{[0.041]}\end{array}$ & $\begin{array}{c}0.024 \\
{[0.046]}\end{array}$ \\
\hline & Corn & $\begin{array}{c}-0.011 \\
{[0.012]}\end{array}$ & $\begin{array}{c}-0.016 \\
{[0.017]} \\
\end{array}$ & $\begin{array}{c}-0.022 \\
{[0.021]}\end{array}$ & $\begin{array}{l}-0.024 \\
{[0.028]}\end{array}$ & $\begin{array}{c}-0.023 \\
{[0.034]}\end{array}$ & $\begin{array}{l}-0.018 \\
{[0.036]}\end{array}$ & $\begin{array}{c}-0.005 \\
{[0.012]}\end{array}$ & $\begin{array}{c}-0.009 \\
{[0.017]}\end{array}$ & $\begin{array}{c}-0.014 \\
{[0.022]}\end{array}$ & $\begin{array}{c}-0.012 \\
{[0.029]}\end{array}$ & $\begin{array}{c}-0.004 \\
{[0.034]} \\
\end{array}$ & $\begin{array}{c}-0.007 \\
{[0.038]}\end{array}$ \\
\hline \multirow{3}{*}{ 2SLS } & Cotton & $\begin{array}{c}-0.052 * * * \\
{[0.020]}\end{array}$ & $\begin{array}{c}-0.066^{* *} \\
{[0.027]}\end{array}$ & $\begin{array}{l}-0.057 * \\
{[0.032]}\end{array}$ & $\begin{array}{l}-0.040 \\
{[0.042]}\end{array}$ & $\begin{array}{c}-0.055 \\
{[0.051]}\end{array}$ & $\begin{array}{c}-0.031 \\
{[0.055]}\end{array}$ & $\begin{array}{l}-0.030 * \\
{[0.016]}\end{array}$ & $\begin{array}{c}-0.068 * * \\
{[0.026]}\end{array}$ & $\begin{array}{c}-0.095 * * * \\
{[0.033]}\end{array}$ & $\begin{array}{c}-0.112 * * * \\
{[0.042]}\end{array}$ & $\begin{array}{c}-0.165 * * * \\
{[0.051]}\end{array}$ & $\begin{array}{c}-0.150 * * * \\
{[0.057]}\end{array}$ \\
\hline & Wheat & $\begin{array}{c}-0.014 \\
{[0.018]}\end{array}$ & $\begin{array}{c}-0.008 \\
{[0.026]}\end{array}$ & $\begin{array}{c}-0.010 \\
{[0.032]}\end{array}$ & $\begin{array}{c}-0.018 \\
{[0.040]}\end{array}$ & $\begin{array}{c}-0.019 \\
{[0.050]}\end{array}$ & $\begin{array}{c}-0.027 \\
{[0.052]}\end{array}$ & $\begin{array}{c}-0.001 \\
{[0.017]}\end{array}$ & $\begin{array}{c}-0.002 \\
{[0.029]}\end{array}$ & $\begin{array}{c}-0.003 \\
{[0.040]}\end{array}$ & $\begin{array}{c}-0.002 \\
{[0.050]}\end{array}$ & $\begin{array}{c}0.009 \\
{[0.063]}\end{array}$ & $\begin{array}{c}-0.003 \\
{[0.064]}\end{array}$ \\
\hline & Corn & $\begin{array}{c}-0.008 \\
{[0.015]}\end{array}$ & $\begin{array}{c}-0.022 \\
{[0.022]}\end{array}$ & $\begin{array}{c}-0.028 \\
{[0.027]}\end{array}$ & $\begin{array}{c}-0.032 \\
{[0.034]}\end{array}$ & $\begin{array}{c}-0.018 \\
{[0.043]}\end{array}$ & $\begin{array}{l}-0.015 \\
{[0.044]}\end{array}$ & $\begin{array}{c}-0.009 \\
{[0.012]}\end{array}$ & $\begin{array}{c}-0.020 \\
{[0.021]}\end{array}$ & $\begin{array}{l}-0.251 \\
{[0.029]}\end{array}$ & $\begin{array}{l}-0.028 \\
{[0.037]}\end{array}$ & $\begin{array}{l}-0.011 \\
{[0.046]}\end{array}$ & $\begin{array}{c}-0.010 \\
{[0.047]}\end{array}$ \\
\hline $\begin{array}{l}\text { f) Comm. } \\
\text { paper rate }\end{array}$ & Cotton & $\begin{array}{c}-0.433^{* *} \\
{[0.204]}\end{array}$ & $\begin{array}{c}-0.455^{* *} \\
{[0.179]}\end{array}$ & $\begin{array}{c}-0.422 * * \\
{[0.187]}\end{array}$ & $\begin{array}{l}-0.408^{*} \\
{[0.219]}\end{array}$ & $\begin{array}{c}-0.654 * * \\
{[0.290]}\end{array}$ & $\begin{array}{c}-0.061 \\
{[0.238]}\end{array}$ & $\begin{array}{c}-0.372 * * * \\
{[0.139]}\end{array}$ & $\begin{array}{c}-0.660^{* * * *} \\
{[0.168]}\end{array}$ & $\begin{array}{c}-0.664 * * * \\
{[0.176]}\end{array}$ & $\begin{array}{c}-0.704 * * * \\
{[0.202]}\end{array}$ & $\begin{array}{c}-1.046^{* * *} \\
{[0.261]}\end{array}$ & $\begin{array}{c}-0.323 \\
{[0.215]}\end{array}$ \\
\hline \multirow[t]{2}{*}{ OLS } & Wheat & $\begin{array}{c}0.133 \\
{[0.192]}\end{array}$ & $\begin{array}{c}0.240 \\
{[0.169]}\end{array}$ & $\begin{array}{c}0.349 * \\
{[0.178]}\end{array}$ & $\begin{array}{c}0.340 \\
{[0.208]}\end{array}$ & $\begin{array}{c}0.348 \\
{[0.276]}\end{array}$ & $\begin{array}{c}0.278 \\
{[0.227]}\end{array}$ & $\begin{array}{c}0.472 * * * \\
{[0.141]}\end{array}$ & $\begin{array}{c}0.503 * * * \\
{[0.170]}\end{array}$ & $\begin{array}{c}0.447 * * \\
{[0.179]}\end{array}$ & $\begin{array}{c}0.454 * * * \\
{[0.205]}\end{array}$ & $\begin{array}{c}0.475^{*} \\
{[0.265]}\end{array}$ & $\begin{array}{c}0.246 \\
{[0.219]}\end{array}$ \\
\hline & Corn & $\begin{array}{c}0.079 \\
{[0.167]}\end{array}$ & $\begin{array}{c}0.246^{*} \\
{[0.147]}\end{array}$ & $\begin{array}{c}0.166 \\
{[0.155]}\end{array}$ & $\begin{array}{c}0.078 \\
{[0.182]}\end{array}$ & $\begin{array}{c}0.100 \\
{[0.241]}\end{array}$ & $\begin{array}{c}0.228 \\
{[0.198]}\end{array}$ & $\begin{array}{c}0.189 \\
{[0.114]}\end{array}$ & $\begin{array}{c}0.358 * * \\
{[0.138]}\end{array}$ & $\begin{array}{l}0.277^{*} \\
{[0.147]}\end{array}$ & $\begin{array}{c}0.182 \\
{[0.169]}\end{array}$ & $\begin{array}{c}0.228 \\
{[0.218]}\end{array}$ & $\begin{array}{c}0.270 \\
{[0.180]}\end{array}$ \\
\hline \multirow{3}{*}{ 2SLS } & Cotton & $\begin{array}{c}-0.587 * * \\
{[0.267]}\end{array}$ & $\begin{array}{c}-0.365 \\
{[0.247]}\end{array}$ & $\begin{array}{c}-0.189 \\
{[0.255]}\end{array}$ & $\begin{array}{c}-0.033 \\
{[0.294]}\end{array}$ & $\begin{array}{c}-0.141 \\
{[0.386]}\end{array}$ & $\begin{array}{c}0.299 \\
{[0.319]}\end{array}$ & $\begin{array}{l}-0.310 \\
{[0.209]}\end{array}$ & $\begin{array}{c}-0.607 * * \\
{[0.256]}\end{array}$ & $\begin{array}{c}-0.618^{* *} \\
{[0.242]}\end{array}$ & $\begin{array}{c}-0.680 * * \\
{[0.263]}\end{array}$ & $\begin{array}{c}-1.013 * * * \\
{[0.330]}\end{array}$ & $\begin{array}{c}-0.353 \\
{[0.270]}\end{array}$ \\
\hline & Wheat & $\begin{array}{c}-0.010 \\
{[0.255]}\end{array}$ & $\begin{array}{c}0.205 \\
{[0.236]}\end{array}$ & $\begin{array}{c}0.332 \\
{[0.238]}\end{array}$ & $\begin{array}{c}0.220 \\
{[0.270]}\end{array}$ & $\begin{array}{c}0.186 \\
{[0.366]}\end{array}$ & $\begin{array}{c}0.123 \\
{[0.287]}\end{array}$ & $\begin{array}{c}0.283 \\
{[0.208]}\end{array}$ & $\begin{array}{c}0.266 \\
{[0.286]}\end{array}$ & $\begin{array}{c}0.301 \\
{[0.292]}\end{array}$ & $\begin{array}{c}0.278 \\
{[0.320]}\end{array}$ & $\begin{array}{c}0.270 \\
{[0.434]}\end{array}$ & $\begin{array}{c}0.016 \\
{[0.302]}\end{array}$ \\
\hline & Corn & $\begin{array}{l}-0.017 \\
{[0.215]}\end{array}$ & $\begin{array}{c}0.152 \\
{[0.196]}\end{array}$ & $\begin{array}{c}0.082 \\
{[0.209]}\end{array}$ & $\begin{array}{c}0.000 \\
{[0.236]}\end{array}$ & $\begin{array}{c}0.126 \\
{[0.315]}\end{array}$ & $\begin{array}{c}0.185 \\
{[0.243]}\end{array}$ & $\begin{array}{c}0.055 \\
{[0.166]}\end{array}$ & $\begin{array}{c}0.177 \\
{[0.211]}\end{array}$ & $\begin{array}{c}0.121 \\
{[0.219]}\end{array}$ & $\begin{array}{c}-0.067 \\
{[0.245]}\end{array}$ & $\begin{array}{c}0.063 \\
{[0.323]}\end{array}$ & $\begin{array}{c}0.116 \\
{[0.219]}\end{array}$ \\
\hline
\end{tabular}




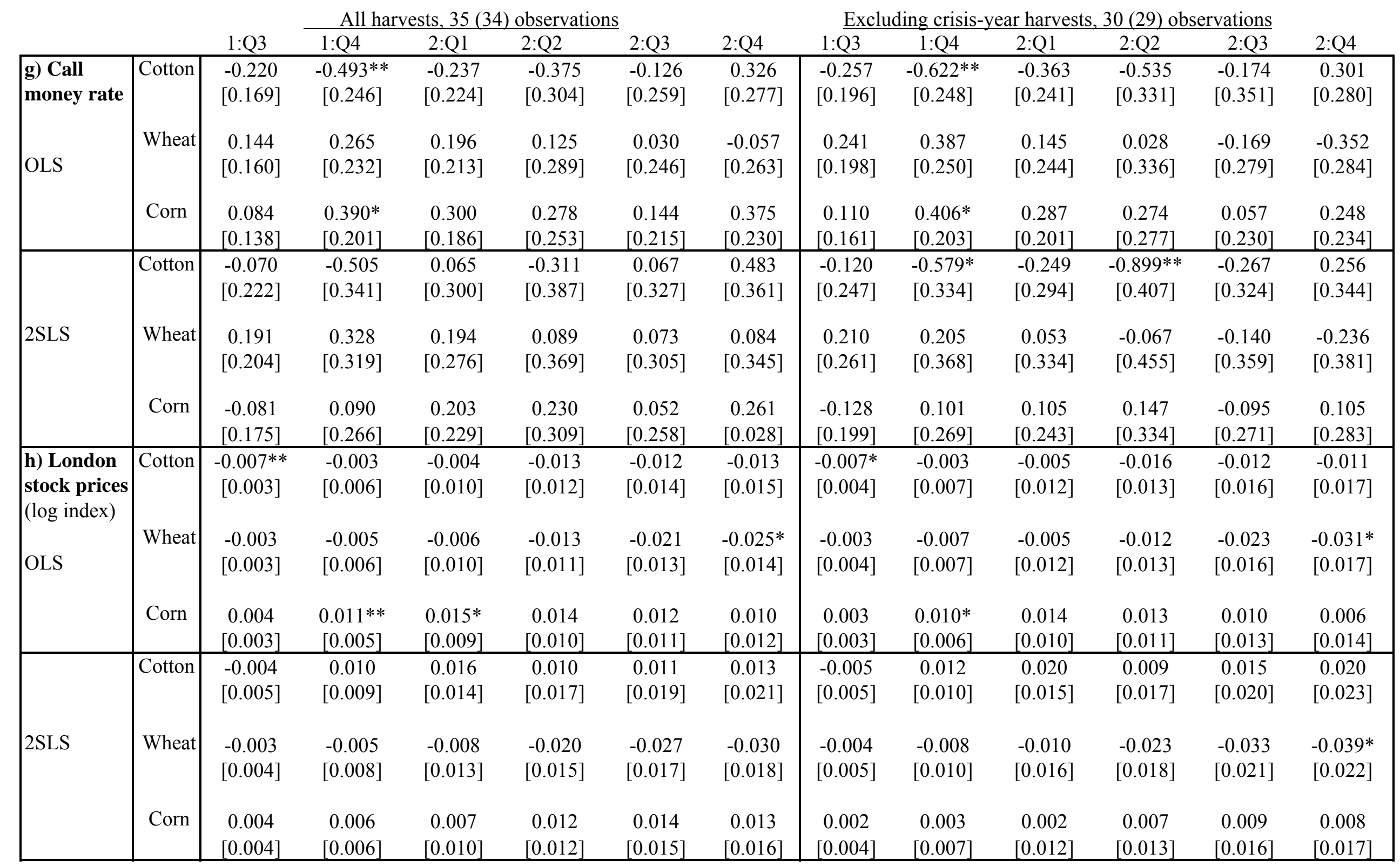




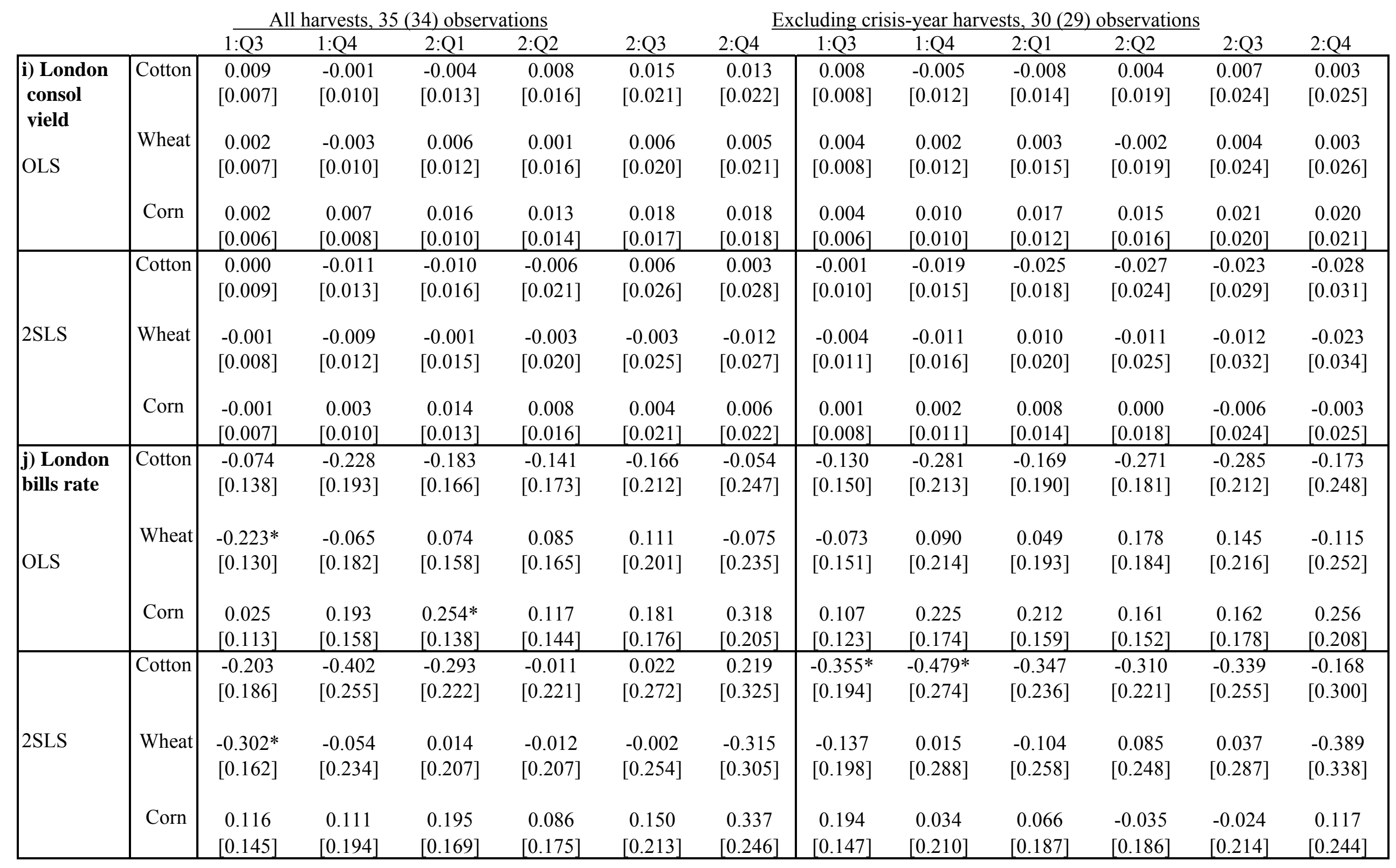




\begin{tabular}{|c|c|c|c|c|c|c|c|c|c|c|c|c|c|}
\hline & & \multicolumn{4}{|c|}{ All harvests, 35 (34) observations } & \multicolumn{8}{|c|}{ Excluding crisis-year harvests, 30 (29) observations } \\
\hline & & 1:Q3 & $1: \mathrm{Q} 4$ & 2:Q1 & $2: \mathrm{Q} 2$ & 2:Q3 & 2:Q4 & 1:Q3 & 1:Q4 & 2:Q1 & $2: \mathrm{Q} 2$ & 2:Q3 & $2: Q 4$ \\
\hline \begin{tabular}{|l|} 
k) Gold \\
inflow
\end{tabular} & Cotton & $\begin{array}{c}0.003 \\
{[0.002]}\end{array}$ & $\begin{array}{c}0.007 \\
{[0.004]}\end{array}$ & $\begin{array}{l}0.008^{*} \\
{[0.005]}\end{array}$ & $\begin{array}{l}0.012^{* *} \\
{[0.005]}\end{array}$ & $\begin{array}{c}0.010 \\
{[0.006]}\end{array}$ & $\begin{array}{c}0.012 \\
{[0.008]}\end{array}$ & $\begin{array}{c}0.005^{* *} \\
{[0.002]}\end{array}$ & $\begin{array}{c}0.009 * * \\
{[0.004]}\end{array}$ & $\begin{array}{c}0.011^{* *} \\
{[0.005]}\end{array}$ & $\begin{array}{c}0.016^{* * *} \\
{[0.006]}\end{array}$ & $\begin{array}{l}0.012^{*} \\
{[0.007]}\end{array}$ & $\begin{array}{c}0.013 \\
{[0.009]}\end{array}$ \\
\hline \multirow[t]{2}{*}{ OLS } & Wheat & $\begin{array}{c}0.002 \\
{[0.002]}\end{array}$ & $\begin{array}{c}0.007 \\
{[0.004]}\end{array}$ & $\begin{array}{l}0.009^{*} \\
{[0.005]}\end{array}$ & $\begin{array}{c}0.013 * * \\
{[0.005]}\end{array}$ & $\begin{array}{c}0.016^{* *} \\
{[0.006]}\end{array}$ & $\begin{array}{l}0.017 * * \\
{[0.007]}\end{array}$ & $\begin{array}{c}0.004 \\
{[0.002]}\end{array}$ & $\begin{array}{c}0.011 * * \\
{[0.004]}\end{array}$ & $\begin{array}{c}0.013 * * * \\
{[0.005]}\end{array}$ & $\begin{array}{c}0.014 * * \\
{[0.006]}\end{array}$ & $\begin{array}{l}0.018 * * \\
{[0.007]}\end{array}$ & $\begin{array}{l}0.020 * * \\
{[0.009]}\end{array}$ \\
\hline & Corn & $\begin{array}{c}0.001 \\
{[0.002]}\end{array}$ & $\begin{array}{c}0.003 \\
{[0.003]}\end{array}$ & $\begin{array}{c}0.004 \\
{[0.004]}\end{array}$ & $\begin{array}{c}0.006 \\
{[0.005]}\end{array}$ & $\begin{array}{c}0.009 \\
{[0.005]}\end{array}$ & $\begin{array}{c}0.013 * * \\
{[0.006]}\end{array}$ & $\begin{array}{c}0.000 \\
{[0.002]}\end{array}$ & $\begin{array}{c}0.003 \\
{[0.003]}\end{array}$ & $\begin{array}{c}0.004 \\
{[0.004]}\end{array}$ & $\begin{array}{c}0.003 \\
{[0.005]}\end{array}$ & $\begin{array}{c}0.007 \\
{[0.006]}\end{array}$ & $\begin{array}{l}0.012 * \\
{[0.007]}\end{array}$ \\
\hline \multirow{3}{*}{ 2SLS } & Cotton & $\begin{array}{c}0.003 \\
{[0.003]}\end{array}$ & $\begin{array}{c}0.005 \\
{[0.006]}\end{array}$ & $\begin{array}{c}0.005 \\
{[0.007]}\end{array}$ & $\begin{array}{c}0.009 \\
{[0.008]}\end{array}$ & $\begin{array}{c}0.010 \\
{[0.009]}\end{array}$ & $\begin{array}{c}0.015 \\
{[0.011]}\end{array}$ & $\begin{array}{c}0.008 * * * \\
{[0.003]}\end{array}$ & $\begin{array}{c}0.017 * * * \\
{[0.006]}\end{array}$ & $\begin{array}{c}0.018 * * * \\
{[0.006]}\end{array}$ & $\begin{array}{c}0.023 * * * \\
{[0.008]}\end{array}$ & $\begin{array}{l}0.023 * * \\
{[0.009]}\end{array}$ & $\begin{array}{l}0.027 * * \\
{[0.012]}\end{array}$ \\
\hline & Wheat & $\begin{array}{c}0.001 \\
{[0.003]}\end{array}$ & $\begin{array}{c}0.007 \\
{[0.005]}\end{array}$ & $\begin{array}{c}0.009 \\
{[0.006]}\end{array}$ & $\begin{array}{c}0.015 * * \\
{[0.007]}\end{array}$ & $\begin{array}{c}0.018 * * \\
{[0.008]}\end{array}$ & $\begin{array}{c}0.020 * * \\
{[0.010]}\end{array}$ & $\begin{array}{c}0.002 \\
{[0.003]}\end{array}$ & $\begin{array}{c}0.009 \\
{[0.006]}\end{array}$ & $\begin{array}{c}0.012 * \\
{[0.007]}\end{array}$ & $\begin{array}{l}0.015^{*} \\
{[0.009]}\end{array}$ & $\begin{array}{c}0.018^{*} \\
{[0.010]}\end{array}$ & $\begin{array}{l}0.022 * \\
{[0.012]}\end{array}$ \\
\hline & Corn & $\begin{array}{l}-0.003 \\
{[0.002]}\end{array}$ & $\begin{array}{l}-0.003 \\
{[0.005]}\end{array}$ & $\begin{array}{c}-0.003 \\
{[0.006]}\end{array}$ & $\begin{array}{c}-0.004 \\
{[0.007]}\end{array}$ & $\begin{array}{c}-0.002 \\
{[0.008]}\end{array}$ & $\begin{array}{c}0.000 \\
{[0.009]}\end{array}$ & $\begin{array}{c}-0.002 \\
{[0.003]}\end{array}$ & $\begin{array}{l}-0.002 \\
{[0.005]}\end{array}$ & $\begin{array}{c}-0.002 \\
{[0.006]}\end{array}$ & $\begin{array}{c}-0.005 \\
{[0.008]}\end{array}$ & $\begin{array}{c}-0.004 \\
{[0.009]}\end{array}$ & $\begin{array}{l}-0.001 \\
{[0.010]}\end{array}$ \\
\hline
\end{tabular}


Table 3 Effects of Cotton Harvest fluctuations excluding pre-crisis harvests

Coefficient scaled to one SD $\log$ harvest fluctuation $=\mathbf{0 . 1 2}$

[SE] also rescaled Significant at $* * * 1$ percent level $* * 5$ percent level 10 percent level

\begin{tabular}{|c|c|c|c|c|c|c|c|}
\hline & & 1:Q3 & $1: \mathrm{Q} 4$ & 2:Q1 & 2:Q2 & 2:Q3 & 2:Q4 \\
\hline \multirow[t]{2}{*}{$\begin{array}{l}\text { a) NYCH deposits } \\
\text { (log dollars) }\end{array}$} & OLS & $\begin{array}{c}0.057 * * * \\
{[0.016]}\end{array}$ & $\begin{array}{c}0.066^{* * *} \\
{[0.017]}\end{array}$ & $\begin{array}{c}0.059 * * * \\
{[0.020]}\end{array}$ & $\begin{array}{l}0.051 * * \\
{[0.023]}\end{array}$ & $\begin{array}{l}0.045^{*} \\
{[0.025]}\end{array}$ & $\begin{array}{c}0.026 \\
{[0.027]}\end{array}$ \\
\hline & 2 SLS & $\begin{array}{c}0.055 * * * \\
{[0.021]}\end{array}$ & $\begin{array}{c}0.059 * * * \\
{[0.023]}\end{array}$ & $\begin{array}{l}0.045^{*} \\
{[0.025]}\end{array}$ & $\begin{array}{c}0.027 \\
{[0.030]}\end{array}$ & $\begin{array}{c}0.021 \\
{[0.033]}\end{array}$ & $\begin{array}{c}0.002 \\
{[0.035]}\end{array}$ \\
\hline \multirow[t]{2}{*}{$\begin{array}{l}\text { b) NY stock prices } \\
(\log \text { index })\end{array}$} & OLS & $\begin{array}{c}0.034 * * * \\
{[0.012]}\end{array}$ & $\begin{array}{l}0.049 * * \\
{[0.020]}\end{array}$ & $\begin{array}{c}0.070 * * * \\
{[0.024]}\end{array}$ & $\begin{array}{c}0.077 * * * \\
{[0.025]}\end{array}$ & $\begin{array}{c}0.079 * * * \\
{[0.027]}\end{array}$ & $\begin{array}{l}0.069 * * \\
{[0.031]}\end{array}$ \\
\hline & 2 SLS & $\begin{array}{c}0.041 * * * \\
{[0.015]} \\
\end{array}$ & $\begin{array}{l}0.067 * * \\
{[0.027]}\end{array}$ & $\begin{array}{c}0.081 * * * \\
{[0.031]}\end{array}$ & $\begin{array}{l}0.070 * * \\
{[0.032]}\end{array}$ & $\begin{array}{c}0.062 * \\
{[0.035]}\end{array}$ & $\begin{array}{c}0.053 \\
{[0.039]} \\
\end{array}$ \\
\hline \multirow[t]{2}{*}{$\begin{array}{l}\text { c) NY stock volume } \\
\text { (log shares) }\end{array}$} & OLS & $\begin{array}{l}0.148^{* *} \\
{[0.060]}\end{array}$ & $\begin{array}{c}0.212 * * * \\
{[0.062]}\end{array}$ & $\begin{array}{c}0.264 * * * \\
{[0.081]}\end{array}$ & $\begin{array}{c}0.293 * * * \\
{[0.073]}\end{array}$ & $\begin{array}{l}0.175^{* *} \\
{[0.069]}\end{array}$ & $\begin{array}{l}0.192 * * \\
{[0.077]}\end{array}$ \\
\hline & $2 \mathrm{SLS}$ & $\begin{array}{c}0.237 * * * \\
{[0.080]} \\
\end{array}$ & $\begin{array}{c}0.268 * * * \\
{[0.081]} \\
\end{array}$ & $\begin{array}{c}0.231 * * * \\
{[0.103]} \\
\end{array}$ & $\begin{array}{c}0.271 * * * \\
{[0.093]}\end{array}$ & $\begin{array}{l}0.195 * * \\
{[0.088]}\end{array}$ & $\begin{array}{l}0.168^{*} \\
{[0.098]}\end{array}$ \\
\hline \multirow[t]{2}{*}{$\begin{array}{l}\text { d) IP } \\
\text { (log index) }\end{array}$} & OLS & $\begin{array}{c}0.006 \\
{[0.022]}\end{array}$ & $\begin{array}{c}0.028 \\
{[0.028]}\end{array}$ & $\begin{array}{l}0.048 * \\
{[0.024]}\end{array}$ & $\begin{array}{c}0.036 \\
{[0.021]}\end{array}$ & $\begin{array}{c}0.053 * * * \\
{[0.020]}\end{array}$ & $\begin{array}{l}0.045^{*} \\
{[0.026]}\end{array}$ \\
\hline & 2 SLS & $\begin{array}{c}0.026 \\
{[0.028]}\end{array}$ & $\begin{array}{c}0.064 * \\
{[0.038]} \\
\end{array}$ & $\begin{array}{l}0.083 * * \\
{[0.032]} \\
\end{array}$ & $\begin{array}{r}0.048^{*} \\
{[0.028]}\end{array}$ & $\begin{array}{c}0.074 * * * \\
{[0.026]}\end{array}$ & $\begin{array}{c}0.046 \\
{[0.034]} \\
\end{array}$ \\
\hline \multirow[t]{2}{*}{$\begin{array}{l}\text { e) NY bond yields } \\
\text { (log index })\end{array}$} & OLS & $\begin{array}{c}-0.050 * * * \\
{[0.015]}\end{array}$ & $\begin{array}{c}-0.066 * * * \\
{[0.023]}\end{array}$ & $\begin{array}{c}-0.071^{* *} \\
{[0.028]}\end{array}$ & $\begin{array}{c}-0.066^{*} \\
{[0.037]}\end{array}$ & $\begin{array}{c}-0.071 \\
{[0.043]}\end{array}$ & $\begin{array}{c}-0.058 \\
{[0.044]}\end{array}$ \\
\hline & 2 SLS & $\begin{array}{c}-0.063 * * * \\
{[0.020]}\end{array}$ & $\begin{array}{c}-0.077 * * \\
{[0.030]}\end{array}$ & $\begin{array}{c}-0.066^{*} \\
{[0.036]} \\
\end{array}$ & $\begin{array}{c}-0.050 \\
{[0.048]} \\
\end{array}$ & $\begin{array}{c}-0.055 \\
{[0.055]}\end{array}$ & $\begin{array}{c}-0.051 \\
{[0.057]}\end{array}$ \\
\hline \multirow[t]{2}{*}{ f)Comm. paper rate } & OLS & $\begin{array}{c}-0.596 * * * \\
{[0.229]}\end{array}$ & $\begin{array}{c}-0.445^{* *} \\
{[0.218]}\end{array}$ & $\begin{array}{l}-0.203 \\
{[0.206]}\end{array}$ & $\begin{array}{c}-0.127 \\
{[0.238]}\end{array}$ & $\begin{array}{c}-0.136 \\
{[0.267]}\end{array}$ & $\begin{array}{c}0.086 \\
{[0.260]}\end{array}$ \\
\hline & $2 \mathrm{SLS}$ & $\begin{array}{c}-0.625^{* *} \\
{[0.297]}\end{array}$ & $\begin{array}{l}-0.321 \\
{[0.285]}\end{array}$ & $\begin{array}{l}-0.050 \\
{[0.265]}\end{array}$ & $\begin{array}{c}0.127 \\
{[0.309]}\end{array}$ & $\begin{array}{c}0.162 \\
{[0.348]}\end{array}$ & $\begin{array}{c}0.348 \\
{[0.338]}\end{array}$ \\
\hline
\end{tabular}


Table 4 Effects of Cotton Harvest Fluctuations Prior to Harvest Season

Changes to 1:Q2

(1) All harvests (2) Excluding crisis-year harvests

\begin{tabular}{|c|c|c|c|c|c|c|c|c|c|c|}
\hline & \multicolumn{2}{|c|}{$\begin{array}{l}\text { NYCH } \\
\text { deposits }\end{array}$} & \multicolumn{2}{|c|}{$\begin{array}{l}\text { NY stock } \\
\text { prices }\end{array}$} & \multicolumn{2}{|c|}{$\begin{array}{l}\text { NY stock } \\
\text { volume }\end{array}$} & \multicolumn{2}{|c|}{$\begin{array}{l}\text { NY bond } \\
\text { yields }\end{array}$} & \multicolumn{2}{|c|}{$\begin{array}{c}\text { Commercial } \\
\text { paper rate }\end{array}$} \\
\hline & (1) & (2) & (1) & (2) & (1) & (2) & (1) & (2) & (1) & (2) \\
\hline OLS & $\begin{array}{l}0.022 \\
{[0.015]}\end{array}$ & $\begin{array}{c}0.016 \\
{[0.016]}\end{array}$ & $\begin{array}{c}0.001 \\
{[0.010]}\end{array}$ & $\begin{array}{l}-0.010 \\
{[0.009]}\end{array}$ & $\begin{array}{l}-0.050 \\
{[0.049]}\end{array}$ & $\begin{array}{l}-0.046 \\
{[0.034]}\end{array}$ & $\begin{array}{l}-0.004 \\
{[0.011]}\end{array}$ & $\begin{array}{l}0.001 \\
{[0.012]}\end{array}$ & $\begin{array}{l}-0.170 \\
{[0.177]}\end{array}$ & $\begin{array}{l}-0.073 \\
{[0.176]}\end{array}$ \\
\hline 2SLS & $\begin{array}{c}0.024 \\
{[0.021]}\end{array}$ & $\begin{array}{c}0.018 \\
{[0.020]}\end{array}$ & $\begin{array}{c}0.028 \\
{[0.015]}\end{array}$ & $\begin{array}{c}0.001 \\
{[0.012]}\end{array}$ & $\begin{array}{l}-0.001 \\
{[0.066]}\end{array}$ & $\begin{array}{l}-0.041 \\
{[0.045]}\end{array}$ & $\begin{array}{l}-0.018 \\
{[0.015]}\end{array}$ & $\begin{array}{c}-0.007 \\
{[0.016]}\end{array}$ & $\begin{array}{c}-0.281 \\
{[0.238]}\end{array}$ & $\begin{array}{l}-0.126 \\
{[0.232]}\end{array}$ \\
\hline
\end{tabular}




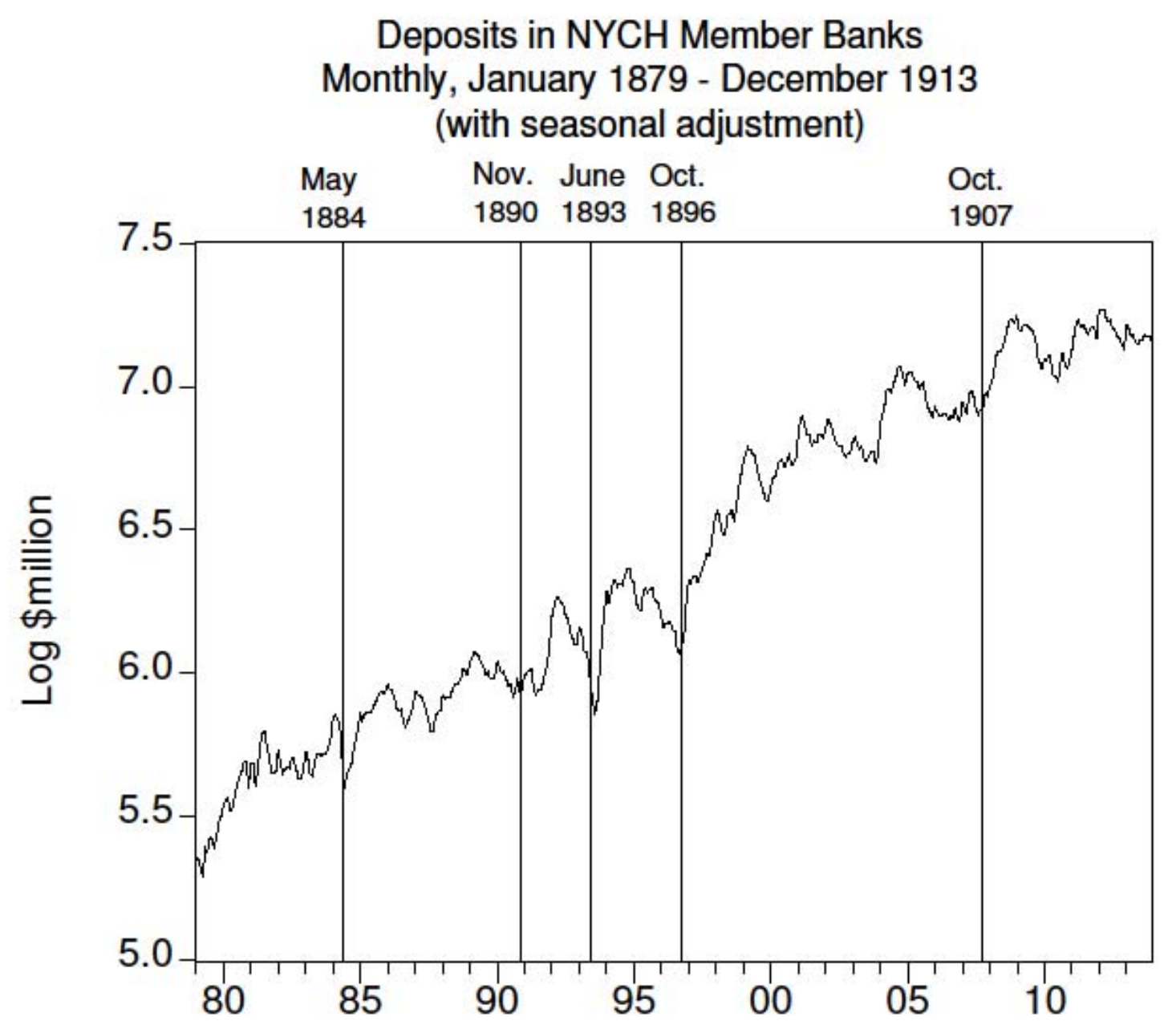


Figure 2

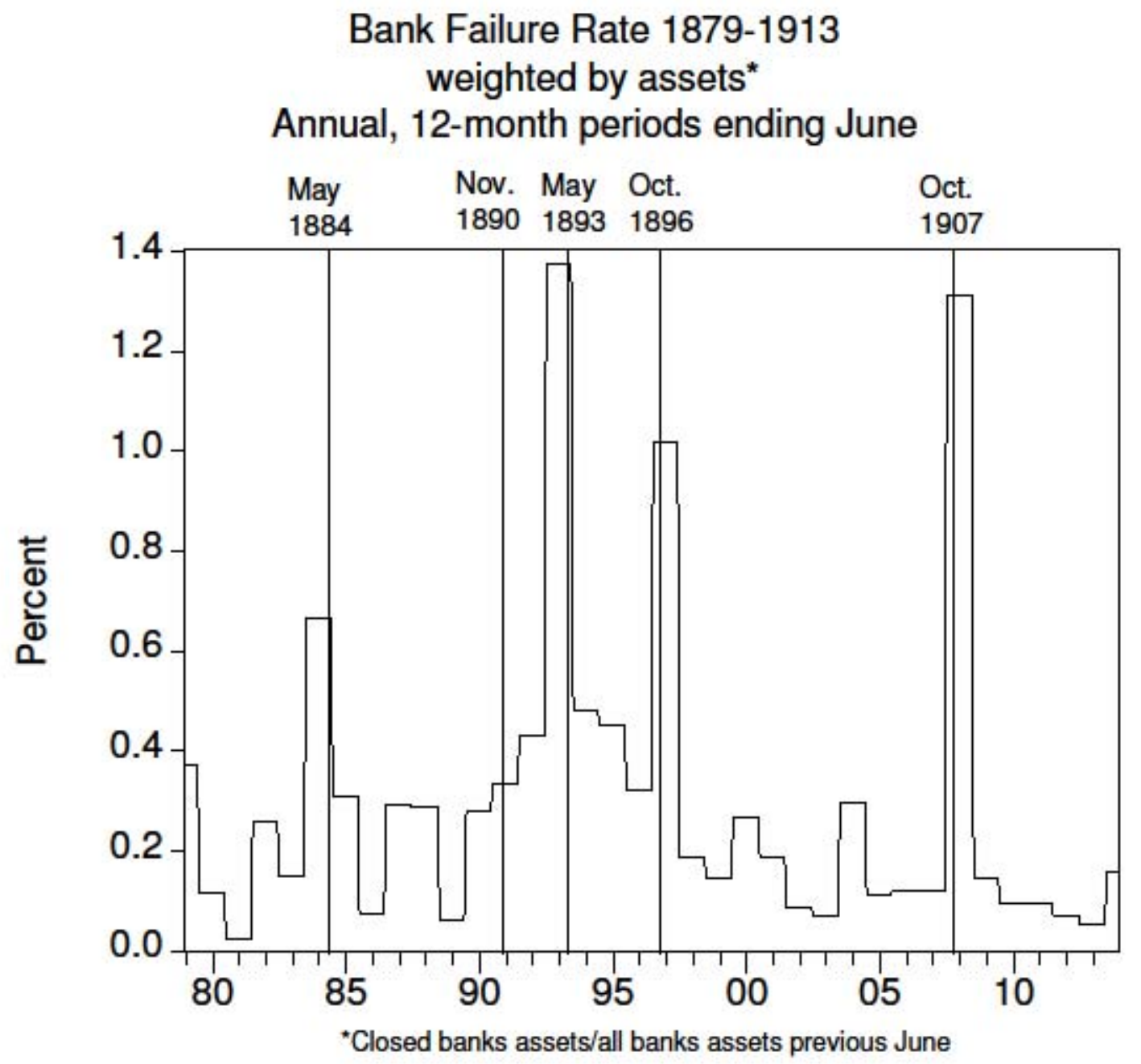


Figure 3

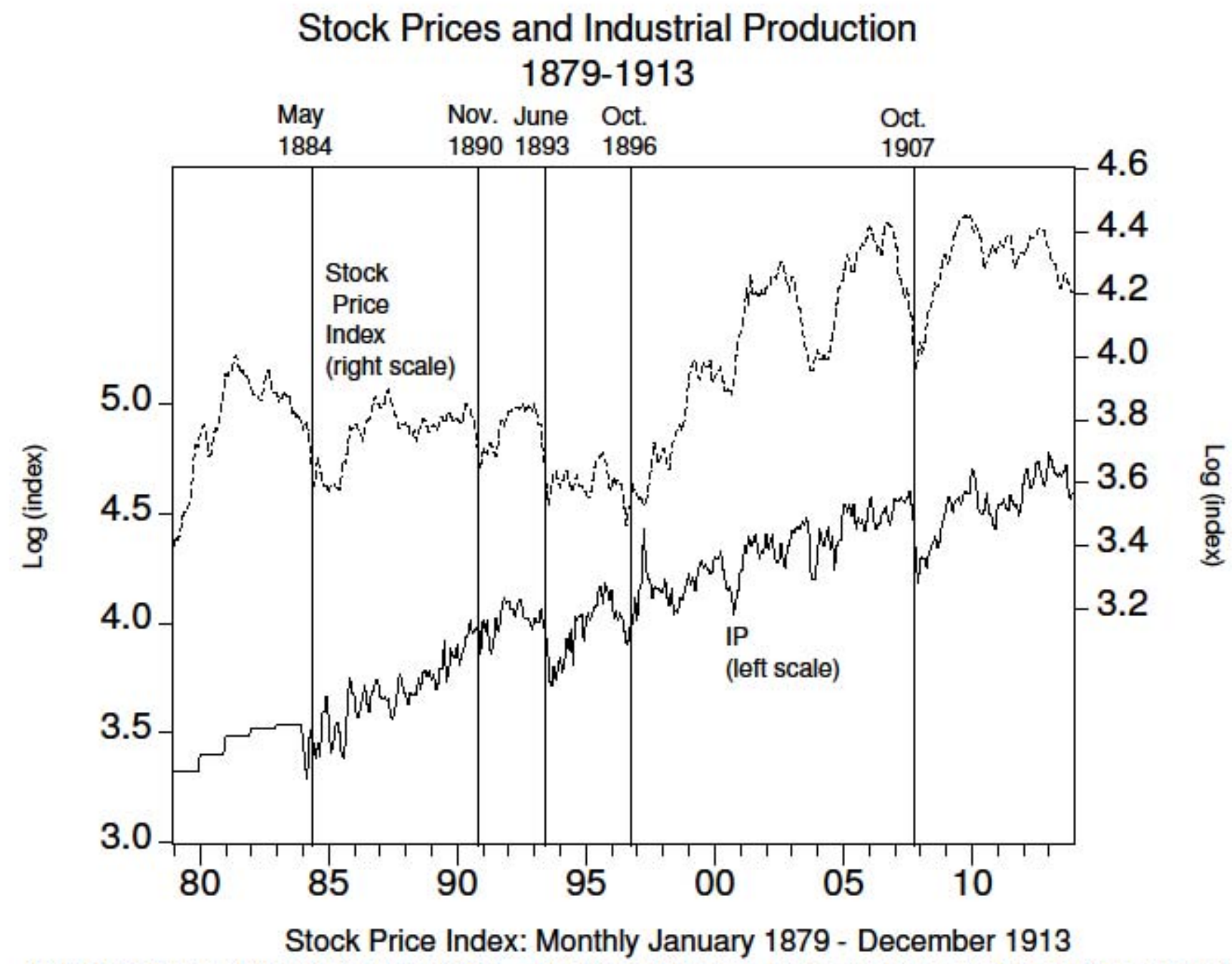

IP Index: Annual (Davis) 1879-1883 Monthly (Miron \& Romer) January 1884-December 1913 SA 


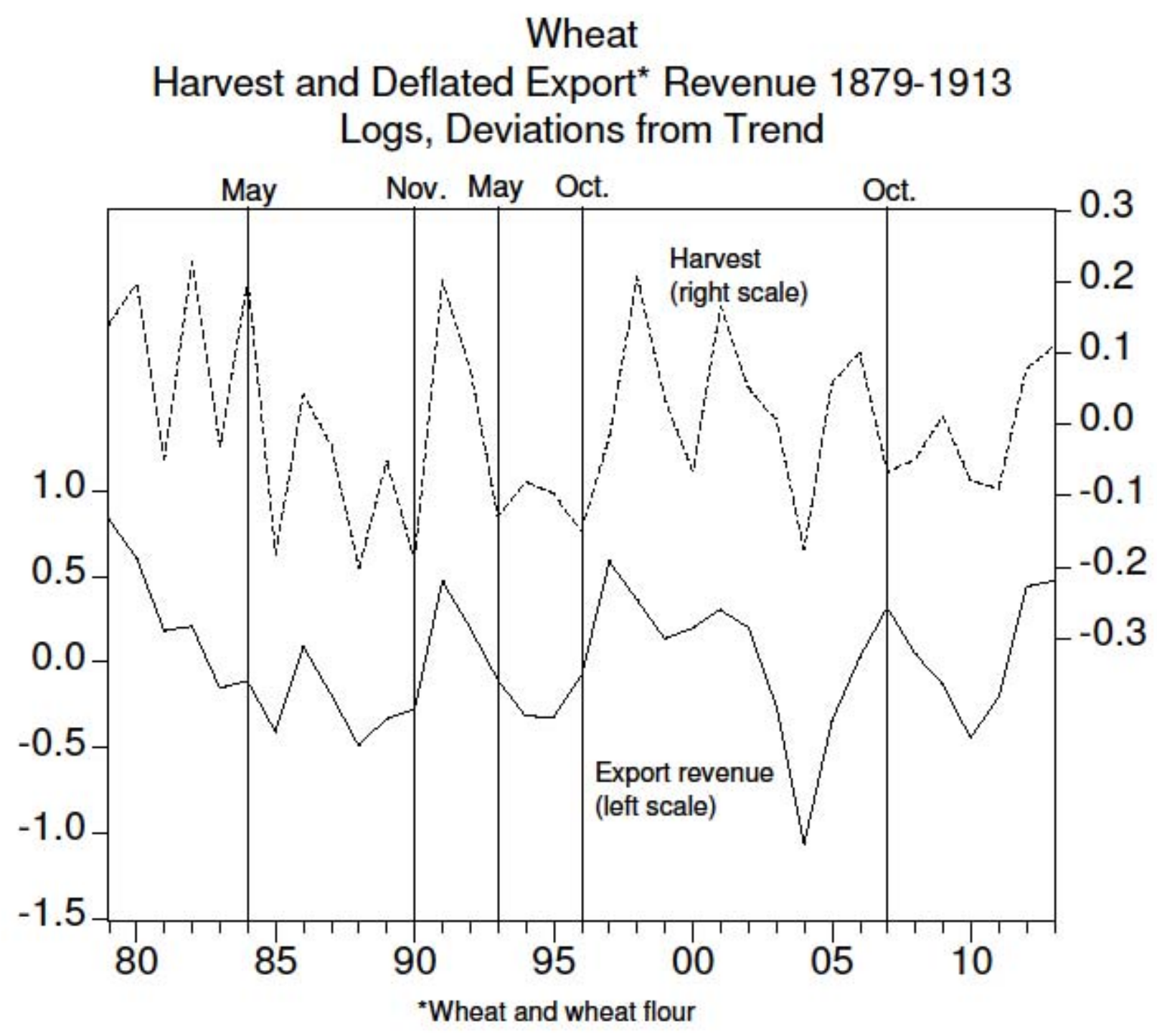


Cotton

Harvests and Deflated Export Revenue, Deviations from Trend 1879-1913

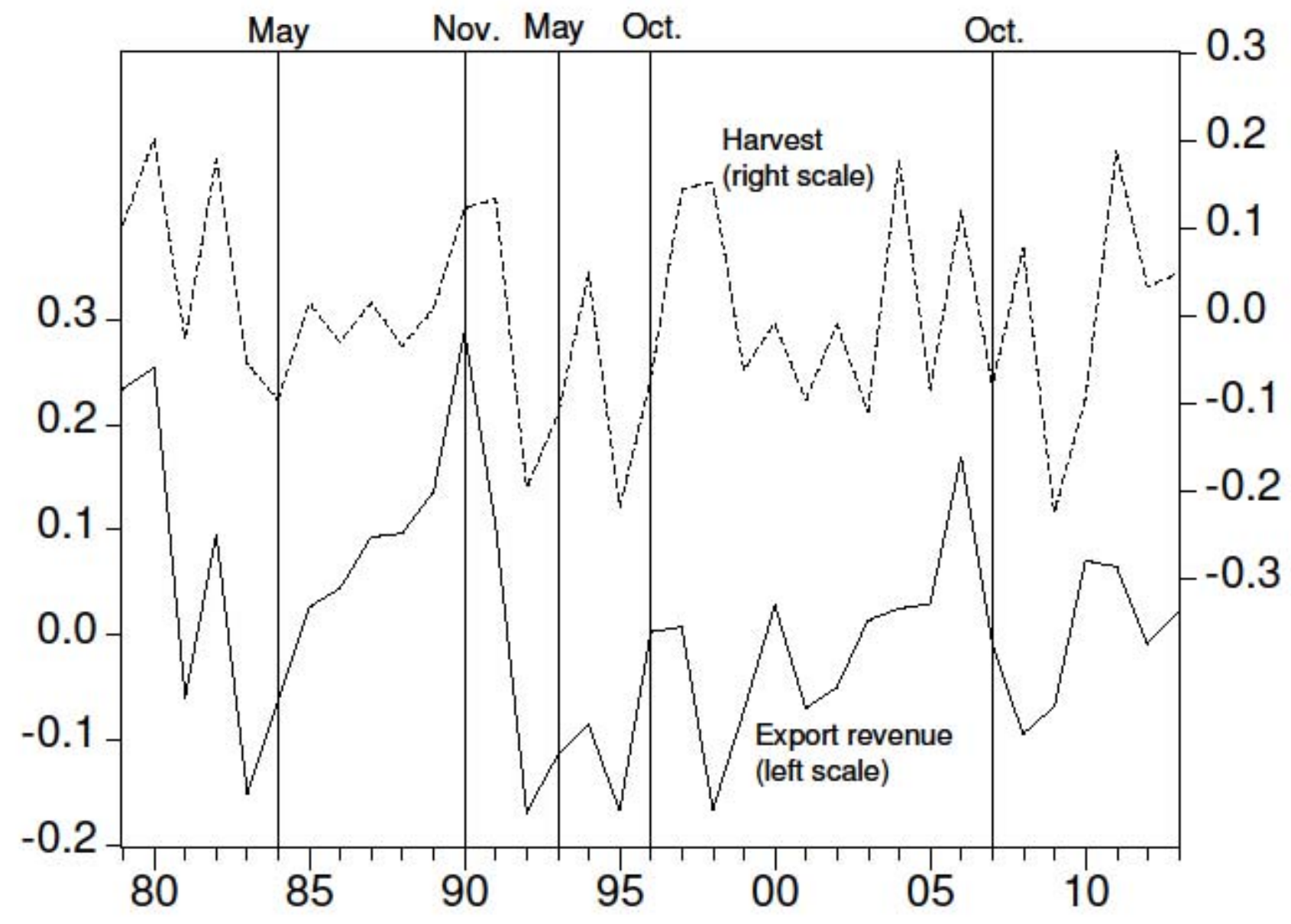


Figure 6

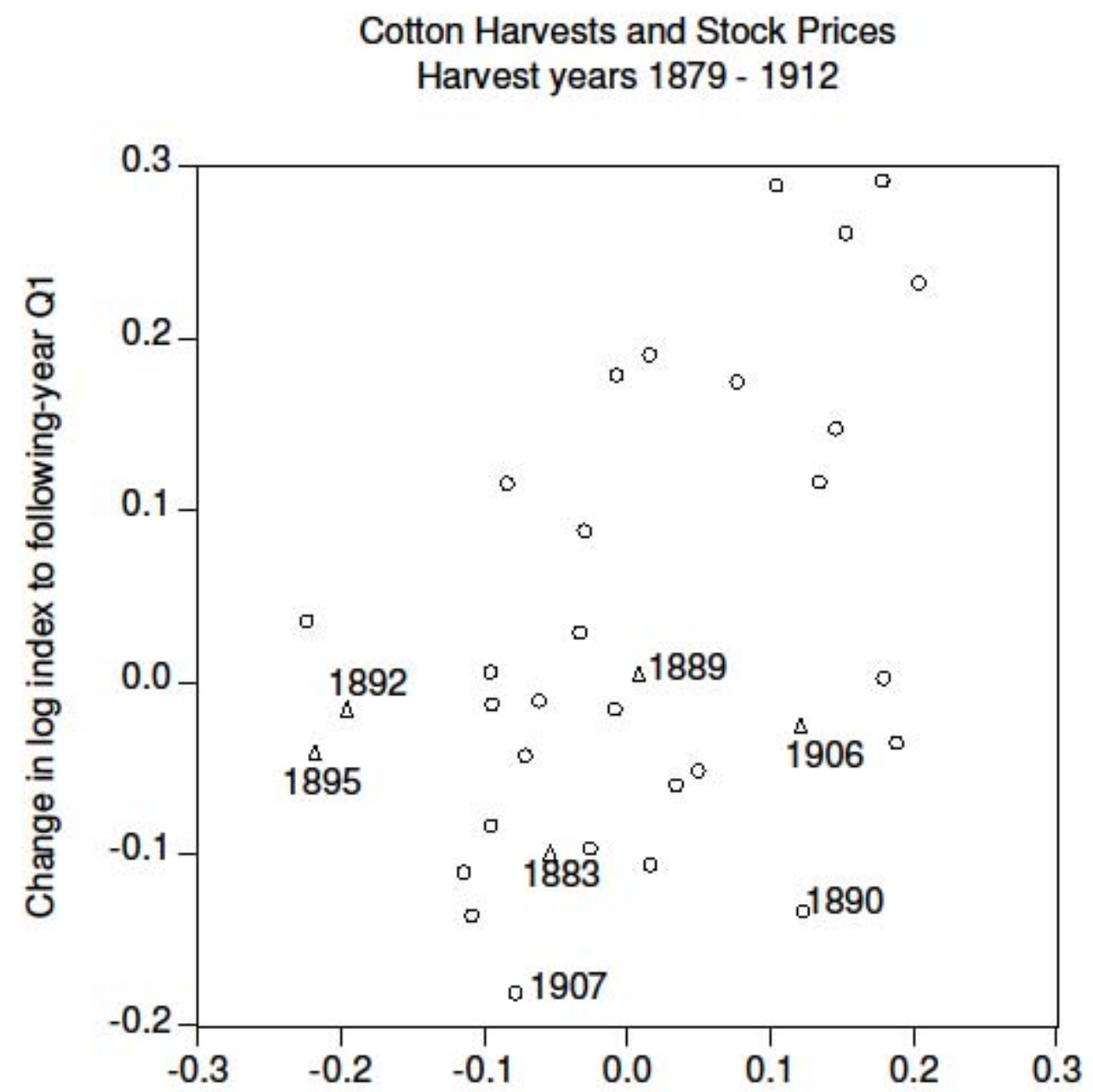

Cotton harvest deviation from trend 
Figure 7

Cotton Harvests and Deposits in NYCH Member Banks Harvest years 1879 - 1912

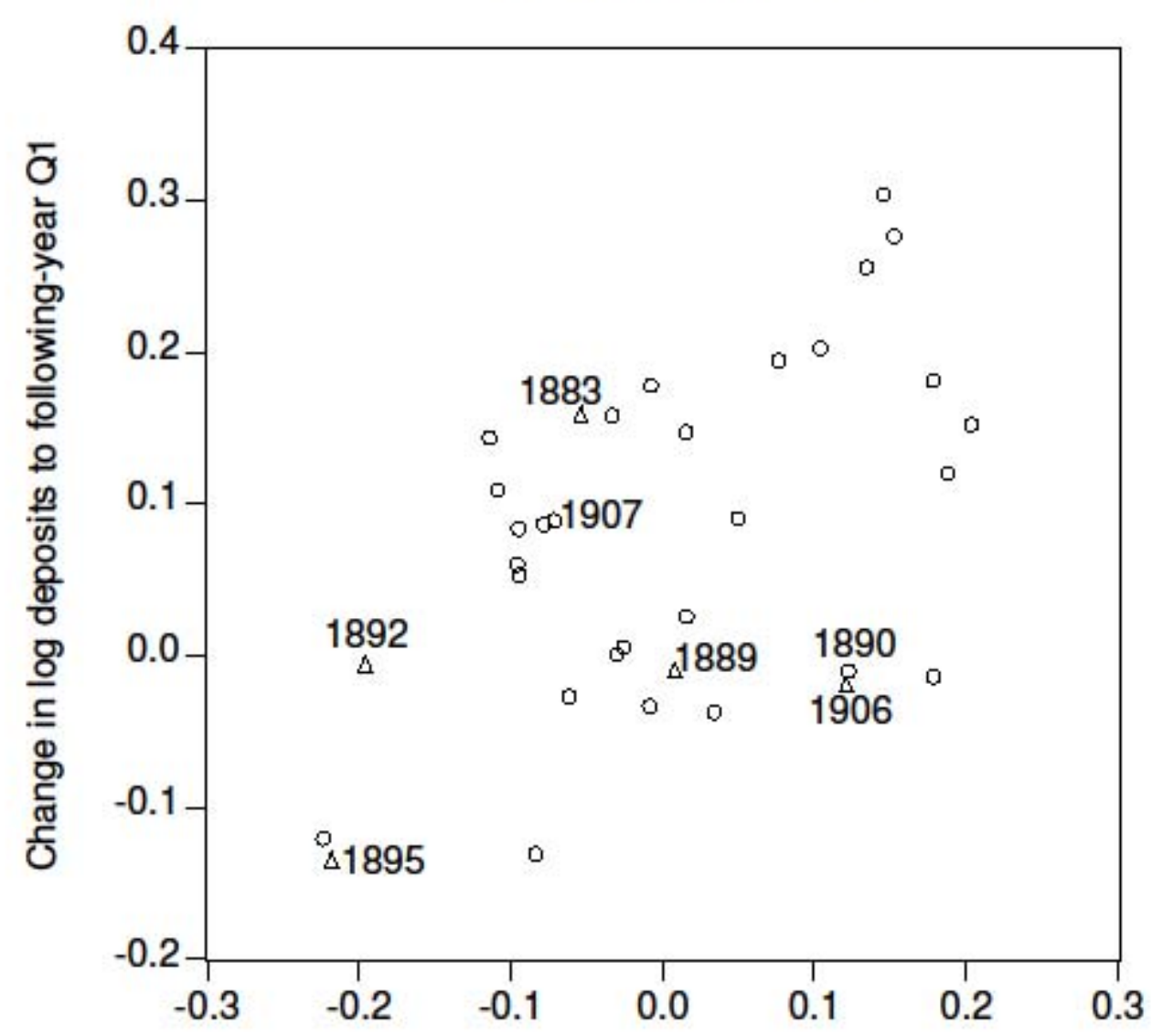

Cotton harvest deviation from trend 


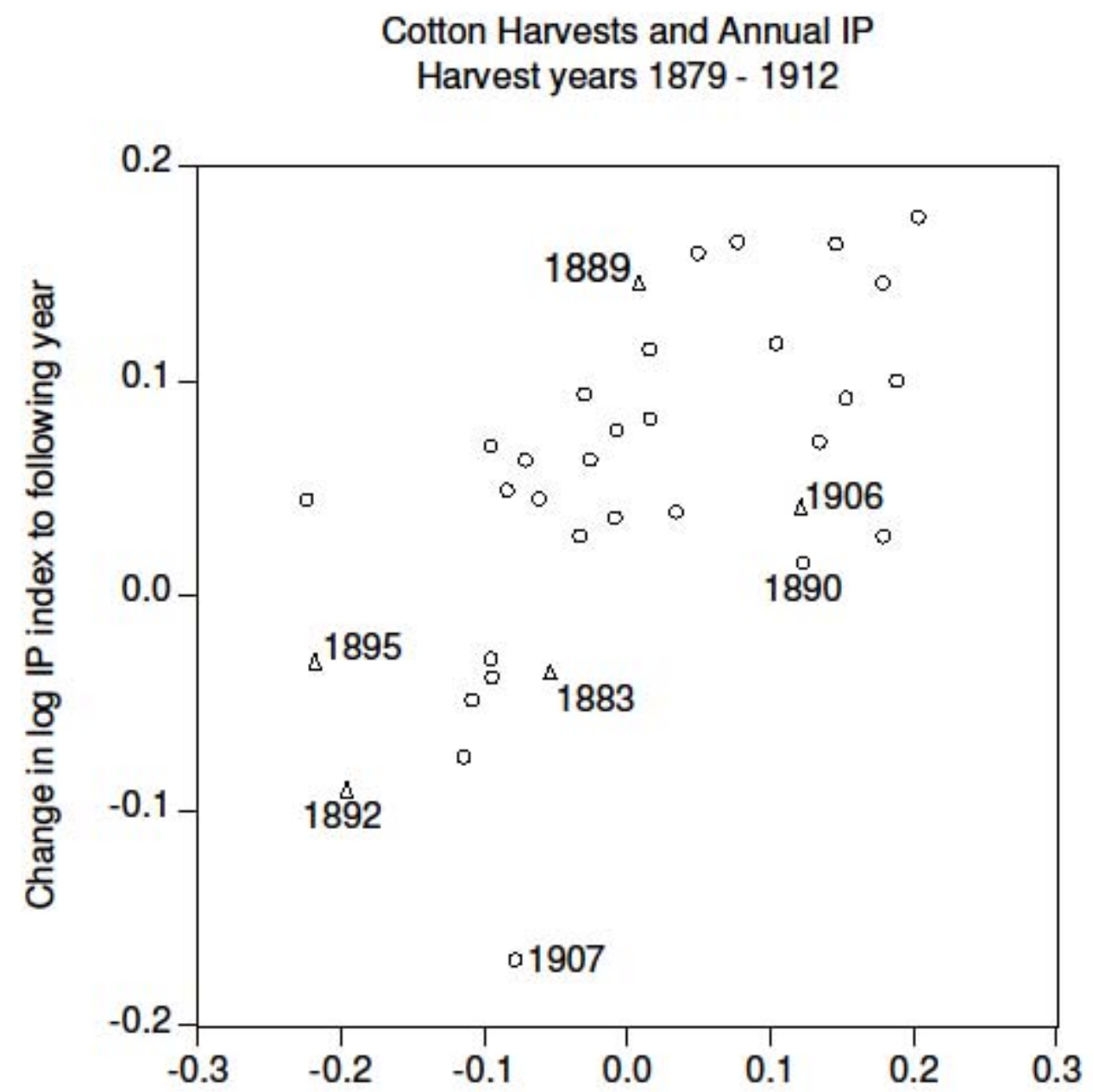

Cotton harvest deviation from trend 